\title{
Dementia in the family
}

Ingun Dina Ulstein

Faculty of Medicine, University of Oslo

Department of Geriatric Medicine and

Norwegian Centre for Dementia Research, Ullevaal University Hospital, Oslo 
C Ingun Dina Ulstein, 2007

Series of dissertations submitted to the

Faculty of Medicine, University of Oslo

No. 566

ISBN 978-82-8072-876-0

All rights reserved. No part of this publication may be

reproduced or transmitted, in any form or by any means, without permission.

Cover: Inger Sandved Anfinsen.

Printed in Norway: AiT e-dit AS, Oslo, 2007.

Produced in co-operation with Unipub AS.

The thesis is produced by Unipub AS merely in connection with the thesis defence. Kindly direct all inquiries regarding the thesis to the copyright holder or the unit which grants the doctorate.

Unipub AS is owned by

The University Foundation for Student Life (SiO) 
... he saw no one clear path to truth

but a thousand paths to a thousand truths far-off and doubtful ...

Sinclair Lewis in Arrowsmith, 1925 


\section{Contents}

Acknowledgement ......................................................................................................

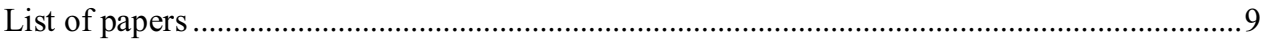

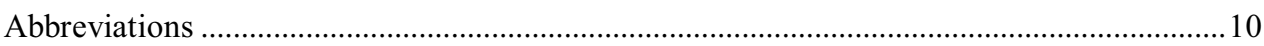

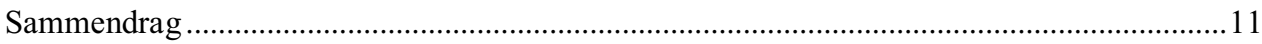

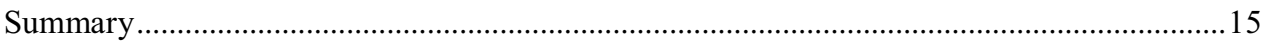

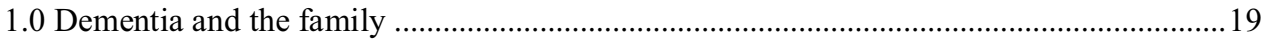

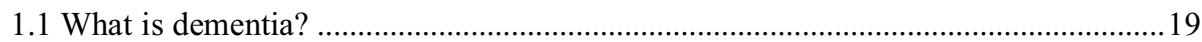

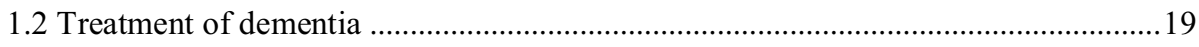

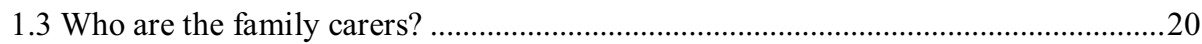

1.4 Why do family members care for persons with dementia?.......................................21

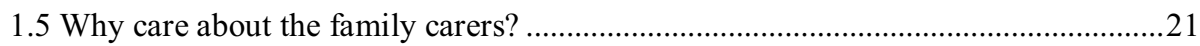

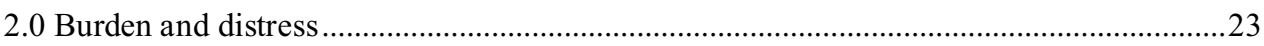

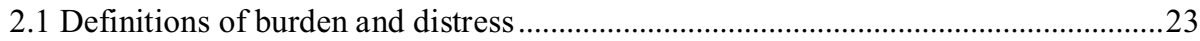

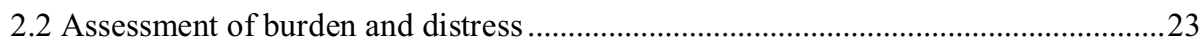

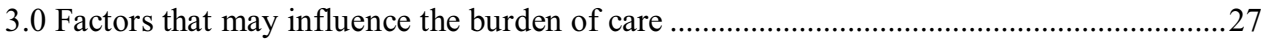

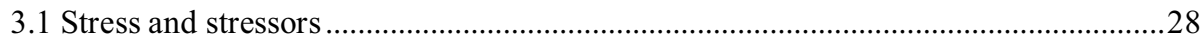

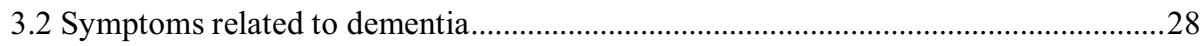

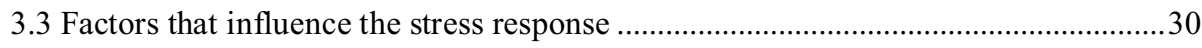

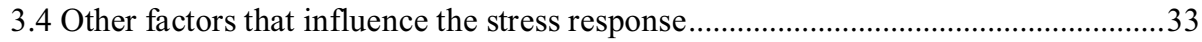

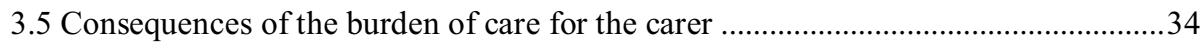

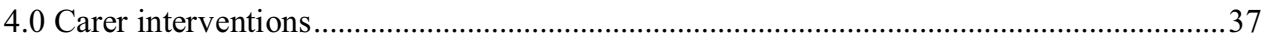

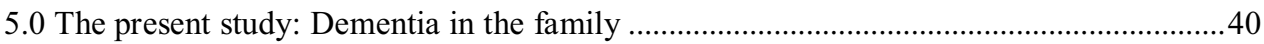

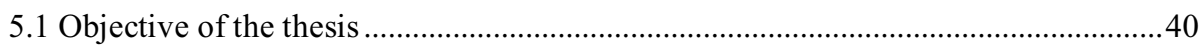

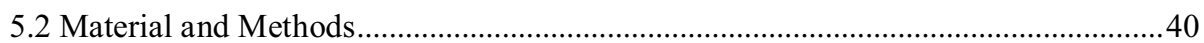

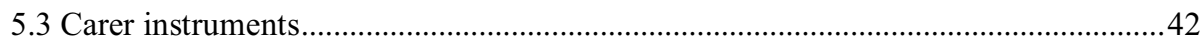

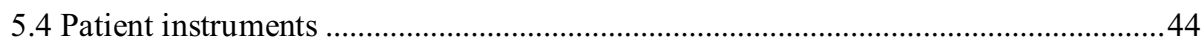

5.5 Assessment instruments used in the cross-sectional studies.......................................45

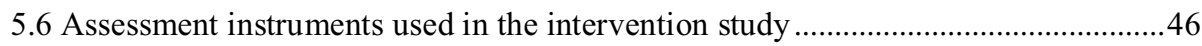

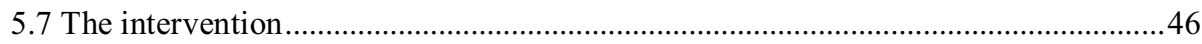

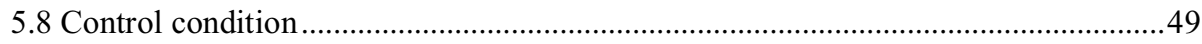

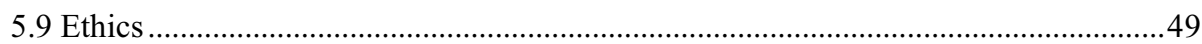

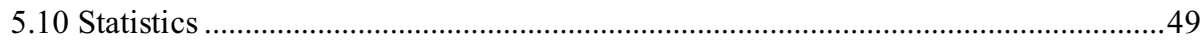

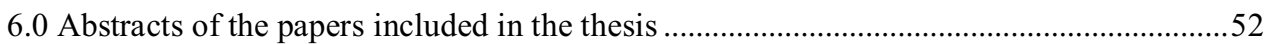

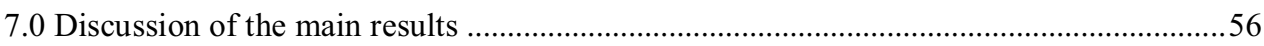

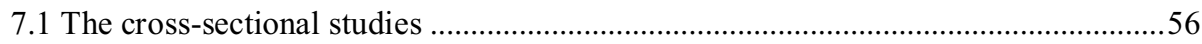

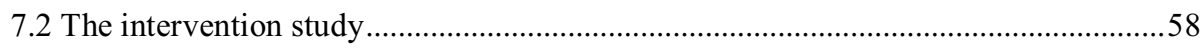

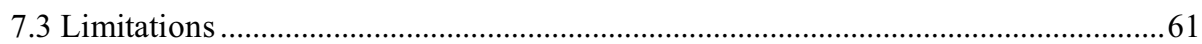

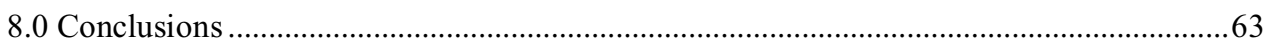

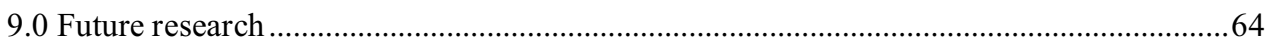

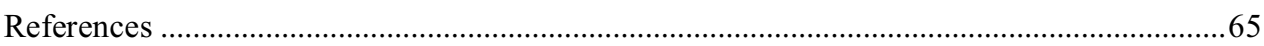

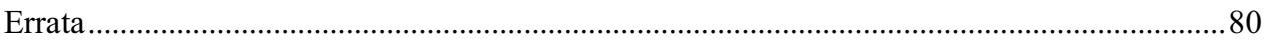

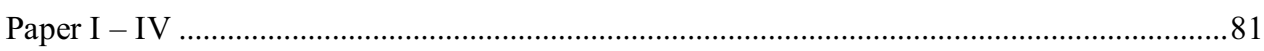




\section{Acknowledgements}

The work presented in this thesis was undertaken in collaboration with the Norwegian Centre for Dementia Research, which supported the study financially and with practical and administrative issues.

I want to express my sincere gratitude to:

- Professor Knut Engedal, my main supervisor, for his support and encouragement throughout the study. He has generously been sharing his knowledge within the field of dementia with me. His excellent pedagogical skills and knowledge concerning methodology has together with his constructive advises and criticism been of invaluable help.

- Professor Torgeir Bruun Wyller, my co-supervisor, who has offered great help and support in the writing process. I would especially thank him for his constructive critical appraisals.

- Professor Leiv Sandvik, who has offered important and inspiring help and support in dealing with the statistical issues.

- The patients and their family carers who participated in this study, sharing time and their experiences with us and thus making the project possible.

I also want to express my gratitude to the memory clinics and geriatric out-patient clinics that took part in the study and provided research assistants to collect data as well as group leaders for the interventions.

Additionally, I would like to thank my co-workers on the project:

- Aud Johannessen, The Norwegian Centre for Dementia Research, Vestfold Mental Health Care Trust

- Tor Erling Dahl and Mette Vinke, the Memory Clinic, Department of Geriatric Medicine, Ullevaal University Hospital, Oslo

- Elin Lillehovde, Peter Horndalsveen, Grete Berg, Berit Rypestøl Finsrud and other coworkers at the Memory Clinic, the Old-Age Department, Innlandet Hospital Trust, Ottestad 
- Elin Vikan Røsæg and Arvid Fikseaunet, Old-Age Psychiatric Out-patients’ Department and Ragna Olaussen, Geriatric Team, Levanger Hospital, Levanger

- Anke Verdeinus, Ellen Sofie Opdahl Mo, Ann-Elin Johansen and Ingvil Saltvedt, Section of Geriatrics, Division of Internal Medicine, St. Olavs University Hospital, Trondheim

- Randi Fauskanger and Harald A Nygaard, Geriatric Out-patients' Department, Haraldsplass Diakonale Hospital and Tone Veland Kutschker, NKS Olaviken Old-Age Out-patients' department, Bergen

- Aud Lilleaas, Berit Båtsveen and Jovan Randjelovic, Old-Age Psychiatric Out-patients' department, Blakstad Hospital, Asker

- Sylvi Jacobsen and Ellen Larsen, the Memory Team, Horten Municipality, Horten.

I also want to thank:

- My colleagues in the "Blakstad-Gaustad Family Project" for their constructive advices.

- My colleagues at the Memory Clinic and "Loftet", Geriatric Department, Ullevaal University Hospital, for their support and interest. Special thanks are due to Kari Kvaal for encouraging me to apply for grants and the discussions throughout the project period. I also thank Aase-Marit Nygaard and Toril Utne for their support and encouragement during periods when progress was slow, and Anne-Lise Eriksen for writing up the transcripts of interviews.

- Lions International (Norway) for a grant through the "Røde fjær aksjonen" that made it possible to employ research assistants.

- The Norwegian Research Council for the grants that made it possible to carry out the project.

I am also grateful to my late father for his support and inspiring discussions, and to my children Lars Kristoffer and Dina Turid for their patience and help throughout the whole project period. And finally I want to thank Bella for her support. 


\section{List of papers}

I. Ulstein I, Bruun Wyller T, Engedal K. 2007. The Relative Stress Scale, a useful instrument to identify various aspects of carer burden in dementia? Int J Geriatr Psychiatry 22: 61-7.

II. Ulstein I, Bruun Wyller T, Engedal K. 2007. High score on the Relative Stress Scale, a marker of possible psychiatric disorder in family carers of patients with dementia. Int J Geriatr Psychiatry 22: 195-202.

III. Ulstein I, Bruun Wyller T, Engedal K. Intrusion and avoidance as stress response symptoms in family carers of patients suffering from dementia. Submitted.

IV. Ulstein I, Sandvik L, Bruun Wyller T, Engedal K. A One-year Randomized Controlled Psychosocial Intervention Study among Family Caregivers of Dementia Patients - Effects on Patients and Caregivers. Submitted. 


\section{Abbreviations}

ADL Activities of Daily Living

BPSD Behavioural and psychiatric symptoms in dementia

DAD Disability Assessment for Dementia Scale

EE Expressed Emotion

GHQ General Health Questionnaire

GDS Geriatric Depression Scale

GP General Practitioner

IES Impact of Event Scale

N Number

NHA Nursing home admittance

NPI Neuropsychiatric Inventory

MMSE Mini Mental State Examination

PTSD Post Traumatic Stress Disorder

RSS Relatives' Stress Scale

STAI-X-1 Spielberg State-Trait Anxiety Inventory 


\section{Sammendrag}

Målsetningen med studien var tredelt:

1. Studere sammenhengen mellom omsorgsgivers opplevelse av omsorgsbyrde, belastning og forskjellige pasient- og pårørendekarakteristika

2. Studere og beskrive stressrespons hos familieomsorgsgivere til pasienter med demens

3. Undersøke om en psykososial intervensjon med undervisning om demens og opplæring i bruk av strukturert problemløsning kan redusere pårørendes belastning og forekomst av atferdsforstyrrelser og psykiatriske symptomer hos personer med demens, og undersøke egenskaper ved pårørende og pasienter som eventuelt har nytte av intervensjonen

\section{Design}

Studien består av to deler; en tverrsnittsstudie der målsetningen var å studere omsorgsbyrde (artikkel I og II) og stressrespons (artikkel III) hos familieomsorgsgiver, og en randomisert, kontrollert, multisenterstudie (artikkel IV) der målsetningen var å studere effekten av en kortvarig psykososial intervensjon rettet mot pårørende til personer med demens.

\section{Utvalg}

Deltagerne var 171 omsorgsgiver/pasientpar rekruttert fra sju hukommelsesklinikker og 25 omsorgsgiver/pasientpar rekruttert fra to pårørendeskoler, til sammen 196 pårørende og 196 pasienter. For å bli inkludert måtte pasienten være hjemmeboende og lide av demens i henhold til ICD-10-kriteriene. Familieomsorgsgiver måtte være i nær slekt med pasienten, ha minst ukentlig ansikt-til-ansikt kontakt og skåre fem eller høyere på Relatives’ Stress Scale (RSS), som er en belastningsskala for pårørende. Tidligere deltagelse i samtalegruppe for pårørende var en eksklusjonsgrunn. Bare pårørende og pasienter rekruttert fra hukommelsesklinikkene deltok i intervensjonsstudien.

\section{Pårørendevariabler}

Belastningsskala for pårørende (RSS), 30-spørsmålsversjonen av General Health Questionnaire (GHQ-30), Geriatrisk depresjonsskala (GDS), 12-spørsmålsversjonen av State-Trait Anxiety Inventory (STAI-X-1), Impact of Event Scale (IES) og belastningsskalaen til Neuropsychiatric Inventory (NPI-D) ble brukt som måleinstrumenter 
ved inklusjon. Ukentlig tid til assistanse ble også beregnet. I intervensjonsstudien ble RSS gjentatt etter 4,5 og 12 måneder.

\section{Pasientvariabler}

Kognitiv funksjon ble undersøkt med Mini Mental Status test (MMS), ADL-funksjon med Disability Assessment for Dementia (DAD) og atferdsmessige og psykiske symptomer (APSD) med Neuropsychiatric Inventory (NPI). I intervensjonsstudien ble NPI gjentatt etter 4,5 og 12 måneder.

\section{Hovedresultater}

Faktoranalyse av RSS resulterte i en tre-faktor løsning; emosjonelt stress (seks spørsmål), sosialt stress (seks spørsmål) og negative følelser (tre spørsmål). I multivariate analyser var APSD den viktigste enkeltfaktor som var assosiert med alle disse tre typene av pårørendebelastning, mens tid til assistanse bidro som en viktig forklaringsvariabel for emosjonelt og sosialt stress. Kvinnelige pårørende ga utrykk for mer emosjonelt stress, mens omsorgsgivere med daglig kontakt med pasienten rapporterte mer begrensninger i sitt sosiale liv. Hustruer til yngre pasienter skåret høyt på negative følelser (artikkel I).

Ved å bruke GHQ-30 og GDS som "gullstandard” var det mulig å beregne grenseverdier for RSS som kan forutsi sannsynlig psykiatrisk sykelighet (RSS > 23) og sannsynlig depresjon hos pårørende $(\mathrm{RSS}>30)$ (artikkel II).

Nesten $50 \%$ av omsorgsgiverne rapporterte et moderat til høyt nivå av gjenopplevelser (intrusion) og unngåelse (avoidance), forenlig med en moderat til høy stressrespons. Ektefeller og pårørende med daglig kontakt med pasienten rapporterte mer symptomer på gjenopplevelse, mens unngåelse var assosiert med det å være ektefelle. Disse symptomene var assosiert med depresjon, angst og belastning knyttet til APSD (artikkel III).

Intervensjonen (undervisning om demens og seks gruppemøter der pårørende fikk opplæring i bruk av strukturert problemløsning) hadde ikke effekt på de to primære effektmålene, RSS og NPI. Belastning målt med RSS økte i både intervensjons- og kontrollgruppen i løpet av oppfølgingsåret. Imidlertid var det flere pårørende fra kontrollgruppen enn fra intervensjonsgruppen som konverterte fra lav belastning til middels eller høy belastning etter 
4,5 måneder. I en undergruppeanalyse fant vi en statistisk signifikant forskjell i kvinnelige pasienters totale NPI-skåre i intervensjonsgruppens favør (artikkel IV).

\section{Kliniske implikasjoner}

Belastningsskala for pårørende (RSS) måler forskjellige aspekter av omsorgsbyrde. I tillegg kan måleinstrumentet brukes til å identifisere omsorgsgivere med risiko for å utvikle psykiatriske symptomer. Pårørende som gir utrykk for høyt nivå av gjenopplevelse og unngåelse antas å kunne ha nytte av en individualisert kognitiv tilnærming. Sammenhengen mellom APSD og omsorgsbyrde innebærer behov for mer effektiv behandling av disse symptomene. En mulighet er å lære pårørende teknikker for å takle APSD. Denne studien viser at dette kan oppnås hos omsorgsgivere til kvinnelig pasienter (ektemenn og voksne barn), mens mannlige pasienter representerer utfordringer som sannsynligvis må møtes med mer intensive, individualiserte tilnærminger. 


\section{Summary}

The specific aims of the study were

- to identify and describe patient and carer characteristics associated with the burden of care on family carers of patients with dementia

- to identify and describe stress responses in family carers of patient with dementia

- to investigate effects on patients and carers of a short-term psychosocial intervention programme for family carers of patients with dementia, and eventually to identify the characteristics of carers and patients who had benefited from the psychosocial intervention

\section{Design}

Two studies were performed. An observational cross-sectional study was carried out to study the burden of care by means of the Relatives' Stress Scale (RSS, Paper I and II) and stress responses of family carers (Paper III). A randomised controlled intervention study was performed to study the effect of psycho-education on carers and patients (Paper IV).

\section{Samples}

For this study, 171 carer/patient dyads were recruited from seven memory clinics and 25 carer/patient dyads from two community-based educational programmes. In all there were 196 carers and 196 patients. To be included the patients had to be residing at home, and suffering from dementia according to the ICD-10 criteria. Only family carers with at least weekly face-to-face contact with the patient and a score equal to or higher than five on the Relatives' Stress Scale (RSS) were included. Carers who had taken part in a carer support programme were excluded. For the intervention study only carers and patients recruited from the memory clinics were included.

\section{Family carer variables}

The Relatives' Stress Scale (RSS), the General Health Questionnaire, 30 -item version (GHQ30), the Geriatric Depression Scale (GDS), the State-Trait Anxiety Inventory, 12-item version (STAI-X-1), the Impact of Event Scale (IES) and the distress scale of the Neuropsychiatric Inventory (NPI-D) were used as measurements at baseline. The weekly hours spent caring for the patients were estimated.

In the intervention study the RSS was repeatedly used at 4.5 months and 12 months after commencement. 


\section{Patient variables}

Cognitive function was assessed by means of the Mini Mental State Examination (MMSE), ADL-function by means of the Disability Assessment for Dementia (DAD) and neuropsychiatric symptoms by means of the Neuropsychiatric Inventory (NPI). In the intervention study the NPI was repeatedly used at 4.5 months and 12 months after commencement.

\section{Main results}

Factor analysis of the RSS resulted in a three-factor solution; emotional distress (six items), social distress (six items) and negative feelings (three items). In a multivariate regression analysis the neuropsychiatric symptoms of the patients was the most important single factor that was associated with the three various kinds of carers' distress, whereas the weekly hours spent caring for the patient contributed as an important explanatory factor for emotional distress and social distress. Female carers expressed more emotional distress, whereas carers with daily contact with the patient reported more restrictions on their social lives. Wives of younger patients were more likely to score high on the subscale 'negative feelings' (Paper I).

Using the GHQ-30 and the GDS as reference methods, it was possible to estimate cut-off scores on the RSS that predicted probable psychiatric morbidity (RSS $>23$ ) and probable depression (RSS $>30$ ) in the carers (Paper II).

Almost 50 percent of the carers reported moderate to high levels of intrusion and avoidance, consistent with a moderate to high stress response. Spouses and other family carers having daily contact with the patient reported more intrusive symptoms, whereas avoidance was associated with the carer being a spouse. These symptoms were associated with symptoms of anxiety, depression and distress due to the patient's neuropsychatric symptoms (Paper III).

The intervention (education about dementia and six group meetings where the carers were taught how to use a problem-solving method) did not have any effect on the two primary outcome variables, scores on the RSS and the NPI. The burden, as measured by the RSS, increased in the intervention group as well as in the control group during the one-year follow-up. However, more carers in the control group than in the intervention group converted from low distress to medium or high distress after 4.5 months. In a subgroup 
analysis we found a statistically significant difference in total NPI among female patients in favour of the intervention group. (Paper IV)

\section{Clinical implications}

The RSS assesses various aspects of the burden of care. In addition, the scale can be used to identify carers at risk of developing psychiatric morbidity. Carers who are expressing high levels of intrusive feelings and avoidance will probably benefit from an individualised cognitive approach. The strong association between the behavioural and psychiatric symptoms in dementia (BPSD) and burden of care implies a need for more effective treatment for those exhibiting these symptoms. One option is to teach the carers how to tackle those symptoms. This study shows that this can be achieved in carers of female patients, whereas male patients may present challenges that have to be met with a more intensive, individualised approach. 


\subsection{Dementia and the family}

\subsection{What is dementia?}

Dementia is a term derived from Latin (de-mens) meaning "no mind". It is a chronic, usually progressive syndrome that embraces symptoms like decline in memory and other cognitive abilities such as deterioration in judgement and thinking, executive functions and the general processing of information. The symptoms influence the patients' performance of the activities of daily living (ADL) and behaviour. Dementia is characterised by decline in emotional control or motivation and a change in social behaviour manifest as emotional instability, irritability, apathy or coarsening of social behaviour. The symptoms have to be present for six months to obtain a confident clinical diagnosis. The syndrome is defined in the International Classification of Diseases - 10th edition (ICD-10 (2004) and in the American Diagnostic and Statistical Manual of Mental Disorders, 4th edition (DMS-IV-TR) (2000).

The most common causes of dementia are Alzheimer's disease (AD) and cerebrovascular disease. Other causes are Diffuse Lewy-body disease (DLB), frontotemporal lobe degeneration and Parkinson's disease (Qizilbash et al., 2002; Engedal, 2002; Engedal and Haugen, 2004).

\subsection{Treatment of dementia}

Some decades ago patients suffering from dementia in Norway were usually taken care of by close family members in their own homes until death. They did not receive much attention from general practitioners (GPs) and other health professionals unless they caused trouble, due to behavioural disturbances or severe ADL-disabilities, and were admitted to a nursing home. Admission to nursing homes has increased in the last thirty years, and today about 80 per cent of nursing home residents in Norway suffer from dementia (Selbaek et al., 2006). When the first anti-dementia drug, tetrahydroaminoacridin (Summers et al., 1986), was introduced, and it turned out that this drug could stabilize or even improve cognition in some patients with Alzheimer's disease, the interest in dementia was aroused among health professionals. Today most countries in the Western world have established memory clinics offering early diagnoses of dementia, and drug treatment with cholinesterase inhibitors for cases of Alzheimer's disease. However, as the effect of the anti-dementia drugs is limited (Courtney et al., 2004; Birks, 2006), other kinds of treatment (like various forms of 
psychosocial approaches that include the family carers) are recommended as additional treatment strategies (Engedal 2002; Green and Brodaty, 2004).

\subsection{Who are the family carers?}

Based upon earlier Norwegian studies (Engedal et al., 1988, Engedal and Haugen, 1993) and the Rotterdam study (Ott et al., 1995), it has been estimated that dementia affects approximately 67,000 persons in Norway (Engedal and Haugen, 2004). The incidence is around 9,000 new cases per year (Engedal, 2002). In Scandinavia two-thirds of those suffering from dementia live in their own homes and are cared for by close family members with some additional formal help (Edhag, 2006). The remaining one-third lives in various residential care homes.

The family members caring for a person suffering from dementia are in the international literature called carers (English) or caregivers (American) (Brodaty and Green, 2000). The family carers are often called informal carers in contrast to formal carers, i.e. care provided by the community. In this thesis we will use the term carer or relative when referring to the family member who is performing care, and patient, person with dementia or care recipient when referring to the diseased family member. According to Zarit and Edwards (1996), carers are usually a close family member (or friend), helping someone on a regular (usually daily) basis with tasks necessary for independent living.

Although there are cultural differences (Brodaty and Green, 2000), the majority of carers are spouses or cohabiters. In most studies they represent over $60 \%$ of the carers. Wives are carers twice as often as husbands. About one of three carers is an adult child, in most cases a daughter or in some rare cases a daughter-in-law. More than 70 per cent of the carers are females (Brodaty and Hadzi-Pavlovic, 1990; Covinsky et al., 2003). Spouses and other family carers living in the same household as the patient are called care providers and are giving direct care and assistance to the person with dementia. Children and other family members living apart from the patient are care managers, because they, in addition to the provision of care, organise formal help for the patient (Brodaty and Green, 2000).

In Norway there are some studies showing that the majority of carers are females. In a study carried out among members of 'Pårørendeforeningen for personer med demens i Oslo', (PADIO) (Lund, 1991) $75 \%$ of the carers were females, $45 \%$ were spouses, $40 \%$ adult 
children, $8 \%$ siblings and $7 \%$ more distant relatives. Six out of 10 carers lived together with the patient. At the memory clinic at Innlandet Hospital Trust the patients were asked to bring a close relative or friend to the consultation. Of 103 patients asked, 57 came together with a spouse or cohabiter, 35 with adult children or children-in law, five with a sibling, and the remaining alone or with a friend or neighbour (Ulstein and Lillehovde, 2000).

\subsection{Why do family members care for persons with dementia?}

There are several reasons for entering the carer role. Some do it out of compassion and love or a wish to repay the patient for earlier happy days. As a wife caring for her seriously disturbed husband stated; 'We have had such a good life together, and I know he would have done the same for me if the situation had been the other way around!' Others enter the carer role due to feelings of duty and guilt, or because they feel under pressure from the situation. These carers are more likely to experience higher levels of distress and feelings of being trapped due to the carer obligation.

Studies have shown that people with dementia who live with a spouse or a cohabite, or have adult children living not too far away, are more likely to stay longer in their own homes when dementia progresses than persons with dementia who lack a family network (Brodaty and Green, 2000).

\subsection{Why care about the family carers?}

It is well documented that being a carer of someone suffering from dementia of any aetiology is stressful (Haley et al., 1987; Baumgarten et al., 1992; Russo et al., 1995; Dunkin and Anderson, 1998; Burns and Rabins, 2000; Pinquart and Sorensen, 2003; Black and Almeida, 2004). Several studies and review articles have demonstrated higher rates of psychiatric symptoms like depression and anxiety among carers compared to age-matched controls (Haley et al., 1987; Gallagher et al., 1989; Schulz et al., 1990; Baumgarten et al., 1992; Pinquart and Sorensen, 2003; Black and Almeida, 2004). Lack of sufficient support and troublesome patient behaviour has been linked to increased risk of depression in carers (Clyburn et al., 2000; Mittelman et al., 2004).

Carers also report a higher use of psychotropic medication and rate their own physical health to be poorer (Burns and Rabins, 2000). They visit their GPs more frequently than non-carers 
and use more prescribed medication and report complications of physical disorders more often (Haley et al., 1987). Still, objective assessments of their health status by trained professionals do not always reveal significant differences between carers and non-carers (Schulz et al., 1995).

It has been documented that depression among carers may increase the risk of depression in the patients and early institutionalisation of the patient (Mittelman et al., 1996; Bedard et al., 1997; Winslow et al., 1999; Hebert et al., 2001; Strain et al., 2003; Mittelman et al., 2006). Moreover, other studies have shown that counselling and support for the carer can reduce depression in both carers and patients and delay nursing home admittance (NHA) (Brodaty et al., 1993; Mittelman et al., 2004).

Further, evidence is found for an association between distress in the carers, higher levels of expressed emotion (EE), and increased levels of behavioural and psychiatric symptoms of dementia (BPSD) in the patient (Vitaliano et al., 1993; Marriott et al., 2000). This may not only result in early NHA (Brodaty et al., 1993; Mittelman et al., 1996), but also an extensive use of psychopharmacological agents with little or questionable effect, which in turn may reduce the quality of life of the patient (Mc Keith and Cummings, 2005). To care about the carer may therefore reduce the negative effects of caring, and improve the patient's situation. 


\subsection{Burden and distress}

\subsection{Definitions of burden and distress}

Several terms are used to describe the hardships that are put upon carers of people suffering from dementia, such as burden, strain, or distress. 'Distress' refers to the emotional aspects of burden, like worries, uneasiness, and concern. The burden of care (or strain), however, is a controversial concept that covers a wider spectrum of reactions associated with the tasks that are put upon the close relatives of a person suffering from a chronic disabling condition, regardless of being of somatic, neurological or psychiatric origin. One of the challenges we encounter when dealing with the concept 'burden of care', is the great variety of definitions used to describe the impact of care.

The definition of burden of care which is most frequently referred to was introduced by George and Gwyther (1986), who defined the carer burden as the physical, psychological or emotional, and financial problems that can be experienced by family members who are caring for an impaired older adult. According to other authors (Poulshock and Deimling, 1984) the burden includes subjective as well as objective elements. The subjective burden (SB) refers to the carers' emotional responses associated with the dementia symptoms and the carer obligations, such as distress, depression, anxiety, irritation and resentment, or feelings of exhaustion and burnout. The objective burden (OB) is associated with the limitations on the carer's social life due to the neuropsychiatric symptoms and the increasing dependency of the patient with cognitive decline and ADL-impairment. The time the carer uses to assist, help and look after the patient and the financial expenses related to dementia, reflect the objective burden as well. Pearlin et al. (1990) introduced the concept primary stressor referring to properties of the patient, whereas secondary stressors reflect the emotional responses of the carer.

Some researchers emphasise the multidimensionality of the concept 'burden of care' (Bedard et al., 2000; Bedard et al., 2005), as 'impact of caring' is defined as 'burden', without considering possible positive aspects of the carer role.

\subsection{Assessment of burden and distress}

The assessment of the burden of care is accepted as an important part of the global evaluation of a person suffering from dementia. A burden scale should ideally describe the 
different aspects of the burden of care and identify carers at risk of developing health problems due to their carer obligations. A burden scale should also be sensitive to change.

Most clinicians accept the use of self-administration questionnaires as they offer a quick evaluation, which may be the basis of a more comprehensive investigation when needed. A variety of burden scales exist.

\subsubsection{The Relatives' Stress Scale}

Greene et al. created the Relatives' Stress Scale in 1982, which was used in the present study. The scale covers emotional distress, restrictions on the carers' social life and negative feelings directed towards the patient. It consists of 15 items (see Table 1) and each item is scored at five levels of intensity, from $0=$ 'not at all' to $4=$ 'to a high degree'.

Table 1. The Relatives' Stress scale

1. Do you ever feel you can no longer cope with the situation?

2. Do you ever feel you need a break?

3. Do you ever get depressed by the situation?

4. Has your own health suffered at all?

5. Do you worry about accidents happening to .....?

6. Do you ever feel that there will be no end to the problem?

7. Do you find it difficult to get away on holiday?

8. How much has your social life been affected?

9. How much has the household routine been upset?

10. Is your sleep interrupted by ......?

11. Has your standard of living been reduced?

12. Do you ever feel embarrassed by ......?

13. Are you at all prevented from having visitors?

14. Do you ever get cross or angry with .....?

15. Do you ever feel frustrated at times with .....?

\subsubsection{Other burden scales}

Several other scales are used in clinical practice as well as in research to assess the burden experienced by relatives of patients with dementia. The following scales are frequently used in carer research: 
The Screen for Caregiver Burden (SCB) (Vitaliano et al., 1991) consists of 25 items covering subjective burden (SB; appraised distress in response to the experiences) as well as objective burden (OB; number of potentially negative experiences). The SCB was designed to identify distressing carer experiences rapidly. There is evidence to suggest that changes in OB and SB over time are explained by changes in care recipient functioning and the carer's distress.

The Burden Interview (Zarit et al., 1980) consists of 29 questions focusing on two welldocumented domains; role strain and personal strain (Bedard et al., 2001). The scale covers resentment with the situation as well as the positive aspects of caring. Bedard et al. (2001) has developed a 12 item short version and a 4 item screening version of the Burden Interview with satisfactory psychometric properties.

The Caregiver Burden Inventory (CBI) (Novak and Guest, 1989) is a 24-item scale, consisting of five sub-scales: the time-dependent burden or objective burden (burden caused by restriction on the carer's personal time); the developmental burden (referring to the sense of failure regarding the carer's hopes and expectations); the physical burden (physical stress and somatic disorders); the social burden (role conflicts due to the carer's job and family); and the emotional burden (embarrassment or shame caused by the patient).

The Distress Scale of the Neuropsychiatric Inventory (NPI-D) (Kaufer et al., 1998) can also be a useful instrument with which to assess the distress associated with the patient's behavioural and psychiatric symptoms (BPSD). The scale covers the 12 items of the NPI and is rated on a six-level scale raging from $0=$ 'not at all' to $5=$ 'very severely or extremely'.

To assess the amount of time spent by caring, a self- report questionnaire like Caregiver Activity Survey (CAS) (Davis et al., 1997) can be useful. The carer is asked to estimate the amount of time spent in the last 24 hours on assisting, helping or looking after the patient in doing the following six activities: communication, using transport, dressing, eating, looking after his/her appearance, and other necessary supervision. The questionnaire takes about five minutes to fill in.

\subsubsection{Instruments to screen for psychiatric morbidity in carers}

Many carers are distressed to such an extent that they fulfil the criteria of a depressive disorder, anxiety or other psychiatric conditions (Anthony-Bergstone et al., 1988; Schulz and Williamson, 1991; Baumgarten et al., 1992; Schulz et al., 1995; Clyburn et al., 2000; 
Covinsky et al., 2003; Rinaldi et al., 2005). Scales that measure depression or anxiety could therefore be useful in order to identify carers who are suffering from mental disorders or are at risk of developing such disorders.

The General Health Questionnaire (GHQ) (Goldberg, 1972; Goldberg and Williams; 1988) is considered to be the benchmark in terms of assessing psychological distress and risk of psychiatric morbidity. In addition, depressive symptoms can be rated by means of the Montgomery-Asberg Depression Rating Scale (MADRS) (Montgomery and Asberg, 1979), Geriatric Depression Scale (GDS) (Yesavage et al., 1982), the Zung Self-Rating Depression Scale (Zung, 1965) or the Hospital Anxiety and Depression Scale (HAD) (Zigmond et al., 1983), among other scales.

\subsubsection{The choice of assessment method}

When dealing with carers and the burden of care, we have to remember that carers may feel distressed by the situation, but they seldom consider themselves as patients. Carers may therefore react negatively if they are asked to fill in a questionnaire constructed to tap psychiatric symptoms. So, a burden scale such as the RSS, focusing on general problems associated with the carer role, may be a more legitimate screening instrument. According to a factor analysis, the 15-item RSS covers different aspects of the burden of care (Greene et al., 1982). The questionnaire is quick to complete and can be used by spouses as well as other family carers. It also constitutes a useful basis for discussions with the family carers, and was therefore, chosen in this study. However, although widely used in clinical settings in Norway as well as in Britain, there has up till now not been any studies on the ability of the RSS to identify carers with possible psychiatric morbidity. 


\subsection{Factors that may influence the burden of care}

According to Vedhara et al., (2000) the symptoms of dementia can be looked upon as stressors that trigger a stress response in the carer. However, the stress response is also influenced by several other variables, some associated with the carer, others with the relationship between carer and patient and others with external factors such as formal and informal help (like support from other family members and friends, see Table 2).

Table 2 Factors that may influence the burden of care

\begin{tabular}{|lll|}
\hline Stressors & Patient's and carer's characteristics & Other factors \\
\hline$\bullet$ Cognitive impairment & $\bullet$ Age of patient and carer & $\bullet$ Social support \\
$\bullet$ ADL-impairment & $\bullet$ Gender of, and kinship & $\bullet$ Social network \\
$\bullet$ BPSD & between patient and carer & $\bullet$ Formal help \\
& $\bullet$ Quality of the relationship & $\bullet$ Informal help \\
& between carer and patient & \\
& $\bullet$ Expressed emotion in carer & \\
& $\bullet$ Coping style of carer & \\
& $\bullet$ Education and knowledge & \\
\hline
\end{tabular}

There is an interaction between a stressor and the response to the stressor that may be modified by so-called mediators. Some people adapt to the situation, whereas others react with increased distress or even anxiety and depression which in its turn can have a negative impact on the stressor, see Figure 1.

Figure 1. The association between stressor, stress response and mediators

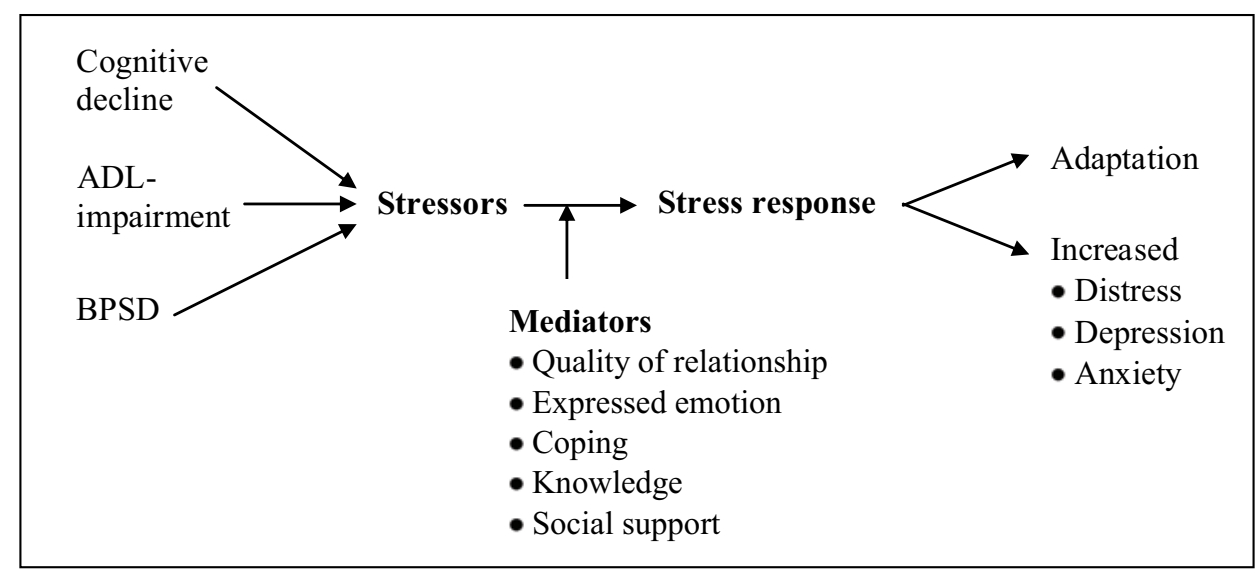




\subsection{Stress and stressors}

\subsubsection{Definition of stress}

The concept stress was introduced by Selye in 1936 and was defined as a nonspecific response of the body to a demand. Psychological stress describes a variety of feelings or reactions accompanying challenging or threatening situations. Stress may have a positive as well as a negative impact on the organism. Milder forms of stress can be stimulating (eustress), whereas a high level of stress (distress) may induce health problems (Selye, 1976).

\subsubsection{Definition of stressor}

A stressor is an agent that produces stress at any time (Selye, 1976). A psychological stressor is defined as any life event or change, such as divorce, marriage, bereavement, loss or change of a job, or moving house, that causes stress and may be associated with the onset or deterioration of a mental disorder (A Dictionary of Psychology in Politics \& Social Sciences, 2006).

\subsection{Symptoms related to dementia}

\subsubsection{Degree of cognitive impairment}

The association between cognitive impairment in the patients and the carers' burden is weak according to most studies (Deimling et al., 1989; Donaldson et al., 1997; Dunkin et al., 1998; Burns and Rabins, 2000; Bedard et al., 2005). According to Pruchno and Resch (1989), carers may feel more burdened when the cognitive decline reaches a stage where the patient needs more help. However, as the degree of cognitive impairment influences both the patient's ability to perform ADL-activities and the prevalence of severe and disturbing neuropsychiatric symptoms, one could assume that it is the consequences of the loss in cognition that distresses the carers, not the loss in cognition itself.

\subsubsection{ADL-impairment}

Another patient variable that may contribute to the burden of care is dysfunction in ADLperformance. Lower ADL-function makes the care recipient more dependent, and the carer may have to spend more hours caring. Most of the earlier studies and review articles on this topic found no certain relationship between impairment in ADL-functioning and burden of care, except for a possible association with depressive symptoms in the carers (Deimling et 
al., 1989; Donaldson et al., 1997). One reason for this could have been the use of inappropriate rating scales or selection bias in the studies (Donaldson et al., 1997). In newer studies an association between dependency in activities of daily living and burden of care is reported (Bedard et al., 2000; Clyborn et al., 2000; Gallicchio et al., 2002; Hèbert et al., 2001; Miller and Cafasso, 2001). Hebert et al., found an association between ADLimpairment and NHA, whereas Covinsky et al. (2003) found that the severity of the dementia, which included dysfunction in ADL-activities as well as increased behavioural disturbances and more hours spent caring, were all predictors of depression in the carers. Mahoney et al. (2005) studied a community sample in London and found an association between ADL-impairment of male care recipients and anxiety in their female carers. However, other factors like a poor relationship and irritability in the patient did influence this finding as well. This reflects the complexity that is found in studying the associations between the carer burden and the symptoms of the patients.

\subsubsection{Behavioural disturbances and psychological symptoms (BPSD)}

BPSD refers to a heterogeneous range of psychological reactions, psychiatric symptoms and behaviour occurring in people with dementia of any aetiology (Finkel, 2000). In this thesis the terms BPSD or neuropsychiatric symptoms will be used, when referring to these noncognitive symptoms displayed by the patients.

Early studies (Greene et al., 1982; Nygaard, 1988, Pearlin et al., 1990) reported a strong association between neuropsychiatric symptoms of the patients and the burden of care. Many of these studies had several methodological weaknesses, such as studying small and heterogeneous samples, which resulted in low statistical power. A broad definition of the concept of burden, and the use of a wide variety of rating scales also made comparisons difficult (Bedard et al., 2000). However, in spite of the shortcomings of the earliest research, newer studies with better methodology and the use of more appropriate measurements and statistics have not brought much new knowledge into this field. According to resent studies, meta-analysis and review articles (Teri, 1997; Clyburn et al., 2000, Black and Almeida, 2004) there are a strong association between the patient's neuropsychiatric symptoms and the burden of care. However, there are also findings suggesting that patients living with highly distressed carers may exhibit more behavioural problems than those living with less distressed carers (Dunkin et al., 1998; Vitaliano et al., 1993). 
In their meta-analysis Black and Almeida (2004) reviewed studies published in English between January 1990 and December 2001 focusing on the association between burden of care, carer depression and rates of institutionalisation of patients. Thirty articles describing cross-sectional data and 12 describing longitudinal data were reviewed. The meta-analysis supported the claim that BPSD are associated with the burden of care, and with psychological distress and depression in the carers. Due to limited longitudinal data it was not possible to conclude whether BPSD caused or predicted the burden of care.

\subsection{Factors that influence the stress response}

\subsubsection{Definition of mediator}

According to Vedhara et al. (2000), a mediator is a construct that enables the person to evaluate the "nature of threat" and the emotional and behavioural responses. However, the mediator is also influenced by the characteristics of the persons themselves as well as the surroundings, see Figure 1. In the following we will look into the characteristics of the carers and the patients, and other factors (mediators) that may influence the stress response of a carer.

\subsubsection{Age of patients and carers}

The age of the patient may influence the burden of care. Older age may be associated with poorer physical health (Schulz et al., 1995) and an increased risk of early nursing home placement (Hebert et al., 2001). If dementia strikes a younger person the situation is quite different. Usually it takes longer for younger patients to obtain a correct diagnosis of dementia (Luscombe et al., 1998), which is distressing not only for the patient but also for the family. This fits well with the research of Covinsky et al. (2003), who found that carers of younger patients were more likely to be depressed. There is also a lack of health services suitable for younger patients with dementia (Freyne et al., 1999). Many carers, especially female carers, may therefore feel obliged to stop working or choose to work part-time to be able to continue home care. Some families may experience negative financial consequences due either to this, or to the early retirement of the diseased person.

\subsubsection{Gender of, and kinship between, patients and carers}

When considering the impact of the patient's gender on burden of care, we have to keep in mind the complex interaction between patient and carer as well. Male patients may exhibit the same amount of difficult behaviour as females. However, the response to this behaviour 
is dependent not only on the carer's gender, but also on factors like the quality of the former and current relationship between the patient and carer (Morris et al., 1988; Fearon et al., 1998). Still, several studies suggest that male patients exhibit more aggressive behaviour than females (Bedard et al., 1997; Lytketos et al., 1999; Gallicchio et al., 2002; Bedard et $a l ., 2005)$, and that aggressive males are more difficult to tackle than aggressive females (Bedard et al., 2005), leading to higher levels of distress in the female carers. There are other explanations why female carers report higher level of distress than male carers (Zarit et al., 1986; Vitaliano et al., 1991; Miller and Cafassio, 1992; Bedard et al., 2005). Most of the female carers are wives giving care to a husband, or daughters caring for a father or mother. Wives and daughters differ in their way of tackling the challenges they are facing, even when they are providing the same kind of care. Wives may experience more restrictions on their social lives, whereas daughters are experiencing greater strain due to the conflicting responsibilities they have to fulfil in their nuclear family, at work and as a care manager (Brodaty and Green, 2000). Further, wives are less likely to ask for help, partly due to role expectations compared to those of daughters and male carers. However, if the home care breaks down due to illness or death of a spouse carer, a daughter is more likely to take over than a son, again due to role expectations.

Some researches have also suggested that male carers are more reluctant to report their level of burden than females are (Lutzky and Knight, 1994), whereas another explanation could be that males and females differ in their way of coping in their carer role (Parks and Pilisuk, 1991). This accord well with previous research showing that female carers are more prone to express distress, depression and anxiety due to their care obligations than males (Morris et al., 1991; Almberg et al., 1998; Gallicchio et al., 1998; Bedard et al., 2005). Males often use a task-oriented or instrumental approach, carrying out their duties in a linear fashion, one by one. Females, on the other hand, are performing their care obligations by nesting activities inside one another in a constant stream of work (Corcoran, 2002). They also tend to be more emotional in their approach (Fitting, 1986), to question their contributions, and to be more prone to guilt feelings that may lead to depression or sustain a depressive mood.

Females also have other care obligations different from those of male carers. In a metaanalysis, Miller and Cafassio (1992) found evidence for the fact that female carers performed more personal care tasks such as toileting or bathing as well as more household tasks compared to male carers, tasks that may well lead to conflicts and outbursts of anger in the 
care recipient. In contrast, many male carers express their belief that they receive much gratitude from giving care to a relative with dementia (Miller and Cafassio, 1992). Retired males get a meaningful obligation with which to fill their lives, and males in general receive more positive appraisals from friends, neighbours etc. when entering the carer role (Bedard et al., 2005).

\subsubsection{Quality of the relationship between patient and carer}

Some studies have found that a poor former relationship between the carer and the care recipient is a predictor of a greater burden and increased risk of depression in the carer, whereas carers who report a close and affectionate past relationship seem to be less burdened (Morris et al., 1988). A poor relationship between the carer and care recipient seems also to be a predictor of anxiety and depression in the carers (Mahoney et al., 2005). If the quality of the relationship is poor, the carer is more likely to react negatively to the symptoms of dementia, such as the patient's exhibition of disruptive behaviour and resentment due to the increased dependency (Brodaty and Green, 2000).

\subsubsection{Expressed emotion}

The emotional atmosphere in the family influences the course of several mental disorders (Brown et al. 1972; Vaugh et al., 1976; Leff and Vaugh, 1985). This phenomenon is known as expressed emotion (EE) and has to do with attitudes like criticism, hostility and emotional over-involvement in close family members of persons suffering from mental disorders.

EE has been studied in dementia. High EE due to criticism is related to increased burden and a maladaptive coping style (Gilhooly et al., 1989; Vitaliano et al., 1991; Donaldson et al., 1997), and is a predictor of the increased occurrence of BPSD (Vitaliano et al., 1993). A sparse social network and no siblings were associated with high EE (Bledin et al., 1990). High EE was also found in couples with a low degree of intimacy (Fearon et al., 1998). Cognition and ADL-function are not directly influenced by EE (Vitaliano et al., 1993). When it comes to emotional over-involvement (EOI) the findings are more insecure. As persons suffering from dementia will be more dependent over time, studies suggest that EOI is not so devastating for the patient (Whittick, 1999). However, the over-involved carers may possibly be more burdened, as they are more likely not to set adequate limits and may have unrealistic expectations concerning the patient's ability to function. 


\subsubsection{Coping abilities}

Carers are a heterogeneous group of people. The fact that a considerable number of carers do report spiritual growth and other positive health effects due to the caring role (Motenko, 1989; Kramer, 1997) has prompted researchers to examine mediators that may explain successful coping. Self-efficacy is such a variable (Steffen et al., 2002) and is defined as the person's belief in their ability to organize and execute courses of action to cope with the challenges of caring (Depp et al., 2005). Carers without such a belief in their ability to cope are more prone to negative thinking and expectations that may lead to feelings of lack of control and subsequent depression and anxiety.

\subsubsection{Education and knowledge}

It is of invaluable importance that the carers have knowledge and understanding of the symptoms of the patient's illness. Early symptoms of dementia such as apathy and lack of initiative, often called "the negative symptoms of dementia" are symptoms that may be interpreted as contrariness. The "normal" reaction to this kind of behaviour is irritation and criticism; responses associated with high levels of EE that may foster unfavourable interactions between carer and patient and increase the occurrence of BPSD (Burns, 2000; Mariott et al., 2000).

According to Graham et al. (1997) carers with knowledge about dementia are less likely to be depressed than less informed carers. Education about dementia may lead to feelings of competence and being in control of the situation and thereby reduce the risk of depression. However, in contrast to this, knowledge may lead to higher levels of anxiety in the carers, probably because they are more aware of the hardships to come (Graham et al., 1997). In a pilotstudy the effect an educational programme called pårørendeskolen was evaluated (Ulstein et al., 2004). The carers who were recruited through newspapers and via district nurses, reported less burden, depression and distress after the programme and 10 months later.

\subsection{Other factors that influence the stress response}

\subsubsection{Social support and network}

According to Lazarus et al. (1984) the social network is a powerful predictor of stressrelated outcomes. Carers with a strong social network, who are satisfied with the support they receive, report fewer burdens (Vitaliano et al., 1991). Carers with a strong social 
network express less depression, greater life satisfaction and report fewer health problems than carers with weak social ties (Haley et al., 1987; Bledin et al., 1990). Social support may increase the self-efficacy of the carer (Depp et al., 2005).

However, some carers who report having a strong social network when care starts, tend to report less satisfaction with their social support over time (Gold et al., 1995). This is probably due to the fact that the carer has to spend more time assisting and helping the patient as dementia progresses, leaving less time over for social contacts. Another explanation is that friends withdraw because they are uncertain about how to relate to the patient. Withdrawal due to fear of causing harm is not an unusual human reaction. However, the carer may also withdraw from friends either to protect the patient or due to embarrassment because of the patient's symptoms and behaviour.

According to a meta-analysis carried out by Donaldson et al. (1997), the loss of family support was related to increased feelings of burden. A lack of social contact may increase the feelings of loneliness and reduce the possibility of obtaining positive feedback from others (Depp et al., 2005).

\subsubsection{Formal help}

The effect of formal help on burden of care in family carers is not conclusive. According to Zarit et al. (1998) the break-down of home care could be prevented by day-centre attendance for the patient twice a week. In their paper they claimed that the carers were less distressed when the patients received day-care service, but most carers waited too long to apply for such a service. According to other studies no significant association exists between the provision of formal help and the burden of care (MaloneBeach, 1992; Flint, 1995).

\subsection{Consequences of the burden of care for the carer}

\subsubsection{Depression}

Studies have suggested that depression in the carer is associated with a complex interplay of factors, some related to characteristics of the patient and others to the carer. The neuropsychiatric symptoms of the patient are according to several studies the main reason for depression in the carers (Schulz et al., 1995; Donaldson et al., 1997; Teri, 1997; Lyketsos et al., 1999; Clyborn et al., 2000; Covinsky et al., 2003; Gaugler et al., 2005; Mahoney et al., 
2005). Some of these studies suggest that difficult behaviour such as anger, irritability and aggression can cause depression in the carers.

Females and spousal carers have a higher risk of developing depression due to their carer obligations than non-spouses and male carers (Schulz et al., 1995; Donaldson et al., 1997). This may be explained by the differences in coping strategies of females and males, older age in spousal carers and distress associated with daily face-to-face contact between spouses. According to several studies there is an association between depression in the carer and an increased risk of depression in the patient (Brodaty et al., 1989; Mittelman et al., 1993; Bedard et al., 1997; Mittelman et al., 2004). However, Mahoney et al. (2005) did not confirm this finding. Other factors related to depression are the carers' perception of poor health, and a low sense of self-efficacy (Depp et al., 2005).

\subsubsection{Anxiety}

According to a newly published review (Cooper et al., 2007), few studies have reported on the association between burden of care and anxiety. One reason for this may have to do with the relatively high association between depression and symptoms of anxiety. Anxiety is more common among carers than in matched controls. In one study neuroticism and the use of avoidance coping was a predictor of anxiety in the short run, but not after 12 months (Vedhara et al., 2000). The authors remain inconclusive concerning the possible risk factors of anxiety. However other studies have found more anxiety among more knowledgeable carers (Graham et al., 1997; Proctor et al., 2002) and carers of more disabled patients when it comes to ADL-functioning (Mahoney et al., 2005).

\subsubsection{Specific stress response symptoms}

Carers of people suffering from dementia are facing a wide range of symptoms and behaviour during the course of dementia, some being looked upon as minor stressors, i.e. daily hassles that can easily be dealt with, whereas other symptoms or situations are more dramatic and can trigger responses that may lead to enduring distress, mimicking reactions we see in post traumatic stress disorders (PTSD).

A 70 year old wife was attacked by her moderately demented husband as she tried to prevent him from driving, by confronting him with the fact that he did not have a valid driver's 
licence. He pulled her by the hair, tried to strangle her, hit her and forced her into a corner from which she was unable to escape. Some weeks later she was actively avoiding thinking about the incident and she felt it had become unreal, as if it hadn't happened. However, talking about it provoked frightening flash-backs, nervousness, tension and disbelief concerning her capacity to cope with the carer situation anymore.

The intrusion and avoidance observed in this woman is in accordance with stress response symptoms described by people who have experienced stressful traumatic events (Horowitz et al., 1979). Intrusion is defined as preoccupation with the incident including distressing thoughts, flashbacks, feelings and nightmares. Even small, often unconscious reminders may evoke intrusion. Indication of avoidance could be a sense of disbelief regarding the incident. Certain ideas, feelings, thoughts, activities, and situations are consciously avoided (DSM-IVRT, 2000; Boye and Malt, 2002). Avoidance may be looked upon as a trial to control the feelings and restore emotional equilibrium. However, this process may be disrupted by new intrusive experiences, leading to a heightened level of defensive control and avoidance (Sundin and Horowitz, 2002). High levels of intrusion and avoidance may prevent the carers from working through the bereavement and sorrow associated with dementia. However these features have not previously been studied in dementia carers. 


\subsection{Carer interventions}

Support groups and educational programmes are offered to reduce the negative effects of giving care to a person suffering from dementia. A variety of intervention programmes are thought to be effective, see Table 3 . Only the most powerful intervention programmes will be described in this overview.

Table 3. Non-pharmacological approaches

\begin{tabular}{ll}
\hline - General information & - Training in how to perform care \\
- Education about dementia & - Relaxation techniques \\
- Support group & - Counselling \\
- Social activities & - Day care centre \\
- Structured problem solving & - Respite care \\
- Cognitive behavioural techniques (CBT) & - Social support \\
\hline
\end{tabular}

Unstructured support groups for carers are offered within clinical settings and by the Alzheimer's Associations world wide, although the evidence is that such groups are less effective than more structured individualised carer interventions (Sörensen et al., 2002; Mittelman et al., 2006).

The term psychosocial intervention (PSI) is used internationally about structured carer interventions including education about dementia, how to tackle distress and losses associated with the disorder, communication skill training and problem solving. However, according to Brodaty et al. (1997) the effect of even such comprehensive training programmes for carers will diminish once dementia has progressed to a later stage. PSI should therefore, if possible, be offered as early as possible in the course of dementia to be cost-effective with respect to delaying nursing home placement.

The aims of PSI are to enable the carers to provide adequate care by reducing the burden and distress in the carers. This may also be achieved by the use of relaxation techniques. These kinds of techniques have therefore been incorporated in some intervention programmes (Marriott et al., 2000). Another important goal of PSI is to increase the carer's social network by helping them to include other family members, or ask friends for help and support. Carers with depressive feelings or anxiety symptoms may benefit from approaches 
like cognitive-behavioural therapy (CBT) (Akkerman and Ostwald, 2004; GallagherThompson et al., 2007) or interpersonal psychotherapy (IPT).

Two large review articles and meta-analyses (Brodaty et al., 2003; Pinquart and Sörensen, 2006) conclude that the effect of most of the carer programmes is questionable. The quality of the PSI research has according to these authors improved over the last years. Earlier studies were small with heterogeneous samples that resulted in low statistical power (Bedard et al., 2000). However, even in the newer studies of better quality, it has been difficult to find evidence that PSI reduces burden of care (Brodaty et al., 2003). This can still have to do with shortcomings in the research designs as well as factors in the carers and patients. The carer will steadily have to face new challenges when dementia deteriorates. Therefore, the interventions have to be flexible as well as of longer duration to meet the changing needs of the carers as well as the patients. Brief educational programmes, support groups alone, single interviews and follow-up in an ordinary clinical setting are usually without any effect, as are short-term interventions without the possibility of a more enduring contact (Brodaty et al., 2003).

An early Cochrane review by Thompson and Spielsbury (1998) was withdrawn in 2003 and is due to be replaced by a new review entitled "Information and support interventions for carers of people with dementia". The reason for withdrawal, according to Thompson, was the huge amount of research reports focusing on information and support as well as cognitive techniques, leading to a decision to divide the field into smaller entities (personal communication). However, this review has still not been published to date, though the protocol is now available at the Cochrane Database (Nelis and Quinn, 2007). Another Cochrane protocol reviewing cognitive and behavioural interventions (Vernooij-Dassen and Downs, 2005) is also available.

Tailored interventions designed to meet the specific needs of the carer and multi-component approaches are superior according to Pinquart and Sörensen (2006), who reviewed 127 intervention studies published between 1982 and 2005. Only multi-component interventions reduced the risk for institutionalisation. Effects of cognitive-behavioural therapy, support, counselling, day-care, training of care recipient, and multi-component interventions were domain specific. 
In contrast to the limited effect of PSI on the burden of care, most carers are satisfied with the programmes they have attended (Brodaty et al., 2003). They report that they are handling the situation as carers better and that their relationship with the patient has improved, maybe through an increased understanding of the disorder. Most carers even express a wish to join such programmes later on.

Although multi-component carer interventions seem to be most appropriate, this kind of programme is seldom available in Norwegian municipalities. Even in a prosperous society like Norway no economical resources have to date been allocated to support programmes for carers. Municipalities with poor economic resources are therefore less likely to give preference to such services, even though they may turn out to reduce the use of healthservices and care services in the long run (Brodaty et al., 1989; Mittelman et al., 1996). The most successful multi-component interventions have also required highly trained therapists such as psychologists and health workers with at least a master's degree (Mittelman et al., 1996; Marriot et al., 2000), whereas most health personnel working with dementia in the municipalities are either enrolled nurses or nurse assistants. In the early stage of dementia, carers may be reluctant to sign in for a comprehensive intervention program as they feel they are coping with the situation. In later stages of dementia carers may be reluctant to sign up for a longer lasting PSI as they find it difficult to get time away from the patient (Green and Brodaty, 2004). Therefore there is a need to develop and evaluate whether a simpler and cheaper short-term PSI programme could have a useful effect on patients with dementia and their carers. In later phases of the disorder they may feel the need of participating in a caregiver support program, but are overwhelmed by caregiving tasks and unable to leave the patient, and do therefore not sign in for such programs. 


\subsection{The present study: Dementia in the family}

\subsection{Objective of the thesis}

The primary object of this thesis was to study the burden of care on carers of patients suffering from dementia by the use of the Relatives' Stress Scale (Greene et al., 1982), and to explore whether this scale could be used to identify carers at risk of developing psychiatric morbidity due to their carer obligations. A second aim was to explore specific stress responses in the carers. The third objective was to evaluate the effect on patients and carers of a short-term psychosocial intervention (PSI) and identify the characteristics of those responding positively to the intervention, if any.

Thus, the specific aims of the study were

- to identify and describe patient and carer characteristics associated with the burden of care in family carers of patients with dementia

- to identify and describe stress responses in family carers of patient with dementia

- to investigate the effects on patients and carers of a short-term psychosocial intervention programme for family carers of patients with dementia, and eventually to identify the characteristics of carers and patients who had benefited from the psychosocial intervention.

\subsection{Material and Methods}

\subsubsection{Design}

Two studies were performed. One observational cross-sectional study was carried out to study the burden of care and specific stress responses in the family carers (Paper I - III). The second study was a randomised controlled intervention study that was performed to study the effect on carers and patients of a short-term psycho-educational programme (Paper IV).

\subsubsection{Sample}

The participants were 171 carer/patient dyads recruited from seven memory clinics and 25 carer/patient dyads from two community-based educational programmes, in all 196 carers and 196 patients. Participants were enrolled from May 2001 to June 2003. To be included in the study the patient had to fulfil the diagnosis of dementia according to the ICD-10 criteria. For the 171 patients recruited from the memory clinics the diagnosis of dementia was made after a comprehensive assessment including a history from both the patients and an informant using standardised rating scales, neuropsychological testing and a physical examination, a 
variety of blood tests and imaging of the brain with cerebral CT or MRI. In a substantial number of cases a SPECT examination was also performed. The patients recruited from the community-based educational programmes were diagnosed by the author (IU), who had experience from the memory clinics at Ullevaal University Hospital and Innlandet Hospital Trust in assessing patients with dementia. The diagnostic work on these patients was similar to that on the memory clinic patients.

Only patients living at home and carers with at least weekly face-to-face contact with the patient and a score equal to or higher than five on the Relatives' Stress Scale (RSS) (Greene et al., 1982) were included. Carers who had taken part in carer support programmes were excluded. For the intervention study only carers and patients recruited at the memory clinics were included. Table 4 shows an overview of the carer/patient dyads included in the different studies.

Table 4. The sample

\begin{tabular}{|l|lll|l|}
\hline \multirow{2}{*}{} & \multicolumn{3}{|c|}{$\begin{array}{c}\text { Cross-sectional Study } \\
\text { (Paper I, II and III) }\end{array}$} & $\begin{array}{c}\text { Intervention Study } \\
\text { (Paper IV) }\end{array}$ \\
\hline Recruited from & $\begin{array}{l}\text { Memory } \\
\text { clinic }\end{array}$ & $\begin{array}{l}\text { Educational } \\
\text { programme }\end{array}$ & Total & Memory clinic \\
\hline Patients & 171 & 25 & 196 & 171 \\
Family carers & 171 & 25 & 196 & 171 \\
\hline
\end{tabular}

The author (IU), trained geriatric and psychiatric nurses, occupational therapists and one carer consultant collected the data. In advance, the research assistants had been trained in the interview technique and how to perform the cognitive testing and to collect data by means of the various standardised evaluation instruments. They were supervised by the author throughout the study to secure reliability.

As the participating memory clinics were rather small and had only a few workers it was impossible to keep the research assistants completely blind as to how the patients and carers were randomised. However, group leaders never assessed carers in the intervention group. When possible, the same research assistant performed all three assessments. The only reason for deviation from this rule was when the research assistant had quit working at the memory clinic concerned. 


\subsection{Carer instruments}

\subsubsection{The Relatives' Stress Scale (RSS)}

The carers completed the Norwegian versions of the Relatives' Stress Scale (RSS) (Greene et al., 1982). The version used in this study has been translated and adapted to Norwegian language and culture by Engedal (1986) with a Chronbach's alpha of 0.90. The RSS consists of 15 items, scored at five levels of intensity; $0=$ 'not at all' to $4=$ 'to a high degree', with a higher score indicating higher levels of burden. According to Braekhus et al. (1998) it is considered to be a one-factor scale.

\subsubsection{The General Health Questionnaire (GHQ-30)}

GHQ-30 is a stress and well-being scale used to rate psychological distress and psychiatric disorders (Goldberg, 1972; Goldberg, 1986). For each item the occurrence of a symptom is rated on a four-point scale $(0-3)$ (Likert's scores) of 'less than usual', 'no more than usual', 'more than usual' and 'much more than usual'. Thus, the GHQ- score can vary from 0 to 90 . A GHQ-case score can be calculated by scoring each item as present $=1$ or absent $=0$, with the total score ranging from 0 to 30. A case score above 5 is considered to be a high score, suggesting clinically significant distress or psychiatric morbidity (Goldberg and Williams, 1988).

\subsubsection{The Geriatric Depression scale (GDS)}

GDS is a screening instrument developed to assess depression in the elderly (Yesavage et al., 1982). It consists of 30 items scored absent $=0$ or present $=1$. A sum score $>11$ indicates depression with a sensitivity of $84 \%$ and a specificity of $95 \%$. If the cut-point score is set to $>14$, the sensitivity is $80 \%$ and the specificity $100 \%$ (Brink et al., 1982).

\subsubsection{The State-Trait Anxiety Inventory (STAI-X-1)}

The STAI-X-1 (Spielberger et al., 1970) measures state anxiety. Each item is rated on a fourlevel ordinal from 'not at all', 'a little', 'quite a lot' to 'very much'. It is one of the most widely used scales to tap anxiety symptoms, and is adapted and translated into more than 60 languages. A State and a Trait version exist. The state part of the scale measures how the persons feel at the moment or recently (Spielberger et al., 1983). Different cut-points for significant anxiety of the state part exists, ranging from 32/33 (Murphy et al., 2002) to 49/50 (Gretarsdottir et al., 2004), and even to 54/55 (Kvaal et al., 2005) in elderly persons. The 
version used in this study is an abbreviated version that was developed by Malt and Olafsen, (1992) to study anxiety associated with post traumatic stress.

\subsubsection{The Impact of Event Scale (IES)}

IES (Horowitz et al., 1979) was originally developed to assess the severity of intrusive and avoidance phenomena associated with bereavement and sorrow. However, the scale was soon used to explore the psychological impact of traumas of various kinds (Sundin and Horowitz, 2002). IES is a self-report scale and consists of 15 items, seven related to intrusive symptoms and eight related to avoidance symptoms. Each item is rated on a six-level scale of never/not at all to marked $(0-5)$. A score of $0-8$ usually denotes a minor response, a score of 9-19 a moderate response, and 20 and beyond a severe (high) response. For the purpose of this study each item was dichotomised into present (the scores 1 to 5), or absent (the endorsement of 0 ).

\subsubsection{The Distress Scale of the Neuropsychiatric Inventory (NPI-D)}

The distress scale of the Neuropsychiatric Inventory (Cummings, 1997; Kaufer et al., 1998) measures the distress associated with the patients' behavioural and psychiatric symptoms (BPSD). The scale covers the 12 items of the NPI and is rated on a six-level scale raging from $0=$ 'not at all' to $5=$ 'very severely or extremely'. The higher the sum score, the higher is the carer's distress associated with the patients neuropsychiatric symptoms. However, to date there is no established cut-point for clinically significant distress.

\subsubsection{The time used to assist and help the patient}

The carers were asked if they did assist or help the patient to perform any activities of daily living. If yes, they were then asked to estimate how much time they had spent assisting, helping or looking after the patient during a typical week in the last month. No attempt was made to validate the carer's report on this. Thus, the scoring reflects the carers' subjective estimates of how much time they spent caring. 


\subsection{Patient instruments}

\subsubsection{Mini Mental State Examination (MMSE)}

Cognitive function was assessed by means of the Mini Mental State Examination (MMSE), (Folstein et al., 1975). MMSE is translated into Norwegian, validated and adapted to the Norwegian language by Engedal and Haugen (Engedal et al., 1988).

\subsubsection{The Disability Assessment for Dementia scale (DAD)}

The activities of daily living were assessed by means of the Disability Assessment for Dementia (DAD) (Gèlinas et al., 1999). DAD includes 17 items related to basic self-care (P$\mathrm{ADL}$ ) and 23 items related to instrumental activities of daily living (I-ADL). The scale also assesses the patient's ability to initiate, plan and execute activities. The carer was asked whether the patient had taken the initiative to perform, prepare and fulfil a task. Scoring alternatives are yes $=1$ or no $=0$. The percentage of tasks that had been carried out in an appropriate way during the previous two weeks was calculated. A DAD\%-score of 100 indicates normal performance, whereas a low score indicates a poor ADL performance. The $\mathrm{DAD}$, according to Gèlinas et al., is not influenced by variables like age and education, but highly related to the Global Deterioration Scale (GDS) (Reisberg et al., 1982).

\subsubsection{The Neuropsychiatric Inventory (NPI)}

The Neuropsychiatric Inventory (NPI) (Cummings, 1997) was used to assess psychological symptoms and behaviour. The NPI covers 12 domains; delusions, hallucinations, agitation/aggression, depression, anxiety, euphoria, apathy, disinhibition, irritability, aberrant motor behaviour, sleep, and eating. Within each domain the family carer was asked a screening question. If they answered yes, specific neuropsychiatric sub-symptoms were assessed. If any of these symptoms were present, the frequency was rated on a four-point frequency scale and the severity on a three-point severity scale. The product of frequency and severity produces the total NPI score within each domain. A score of four and higher is considered to be clinically significant and associated with the need for therapeutic intervention (Schneider et al., 2001; Lyketsos et al., 2002). 


\subsection{Assessment instruments used in the cross-sectional studies}

In the cross-sectional studies we used RSS to explore different aspects of the burden of care. GHQ and GDS were used as benchmarks to establish cut-point values for RSS, and IES to explore specific stress responses associated with the burden, whereas the patients' cognitive decline, their ADL-deficits and neuropsychiatric symptoms were assessed by means of MMSE, DAD and NPI, respectively. Relevant carer and patient characteristics were used to describe the material. An overview of the instruments used in the cross-sectional studies is reported in Table 5.

Table 5 Variables used in the cross-sectional study

\begin{tabular}{|c|c|c|c|c|c|c|}
\hline & \multicolumn{2}{|c|}{ Paper I } & \multicolumn{2}{|c|}{ Paper II } & \multicolumn{2}{|c|}{ Paper III } \\
\hline & Carer & Patient & Carer & Patient & Carer & Patient \\
\hline \multicolumn{7}{|l|}{ Demographics } \\
\hline Age & $X$ & $\mathrm{X}$ & $X$ & $X$ & $\mathrm{X}$ & $X$ \\
\hline Gender & $\mathrm{X}$ & $X$ & $\mathrm{X}$ & $X$ & $\mathrm{X}$ & $\mathrm{X}$ \\
\hline Kinship & $\mathrm{X}$ & $\mathrm{X}$ & $\mathrm{X}$ & $\mathrm{X}$ & $\mathrm{X}$ & $\mathrm{X}$ \\
\hline Living condition & $\mathrm{X}$ & $\mathrm{X}$ & $\mathrm{X}$ & $\mathrm{X}$ & $\mathrm{X}$ & $\mathrm{X}$ \\
\hline Education & $\mathrm{X}$ & $\mathrm{X}$ & $X$ & $\mathrm{X}$ & $X$ & $\mathrm{X}$ \\
\hline Informal help & $\mathrm{X}$ & & $\mathrm{X}$ & & $\mathrm{X}$ & \\
\hline Formal help & & $\mathrm{X}$ & & $\mathrm{X}$ & & $\mathrm{X}$ \\
\hline Duration of symptoms & & $\mathrm{X}$ & & $\mathrm{X}$ & & $\mathrm{X}$ \\
\hline \multicolumn{7}{|l|}{ Carer variable } \\
\hline RSS & $\mathrm{X}$ & & $\mathrm{X}$ & & & \\
\hline NPI-D & & & & & $\mathrm{X}$ & \\
\hline Weekly hours used for assistance & $X$ & & $\mathrm{X}$ & & & \\
\hline GHQ-30 & & & $\mathrm{X}$ & & & \\
\hline GDS & & & $\mathrm{X}$ & & $\mathrm{X}$ & \\
\hline IES & & & & & $\mathrm{X}$ & \\
\hline STAI & & & & & $\mathrm{X}$ & \\
\hline \multicolumn{7}{|l|}{ Patient variables } \\
\hline MMS & & $\mathrm{X}$ & & $\mathrm{X}$ & & $\mathrm{X}$ \\
\hline $\mathrm{DAD}$ & & $\mathrm{X}$ & & $\mathrm{X}$ & & $\mathrm{X}$ \\
\hline NPI & & $\mathrm{X}$ & & $\mathrm{X}$ & & $\mathrm{X}$ \\
\hline
\end{tabular}




\subsection{Assessment instruments used in the intervention study}

In the intervention study the primary outcome variables of effect of PSI were RSS to assess effect on carers, and NPI to assess effect on the patients. Secondary outcome variables were scores on the MMSE and DAD. In addition, relevant carer and patient background characteristics were used to describe the material and establish subgroups of patients and carers to explore subgroup analyses (see Table 6).

Table 6 Variables used in the intervention study

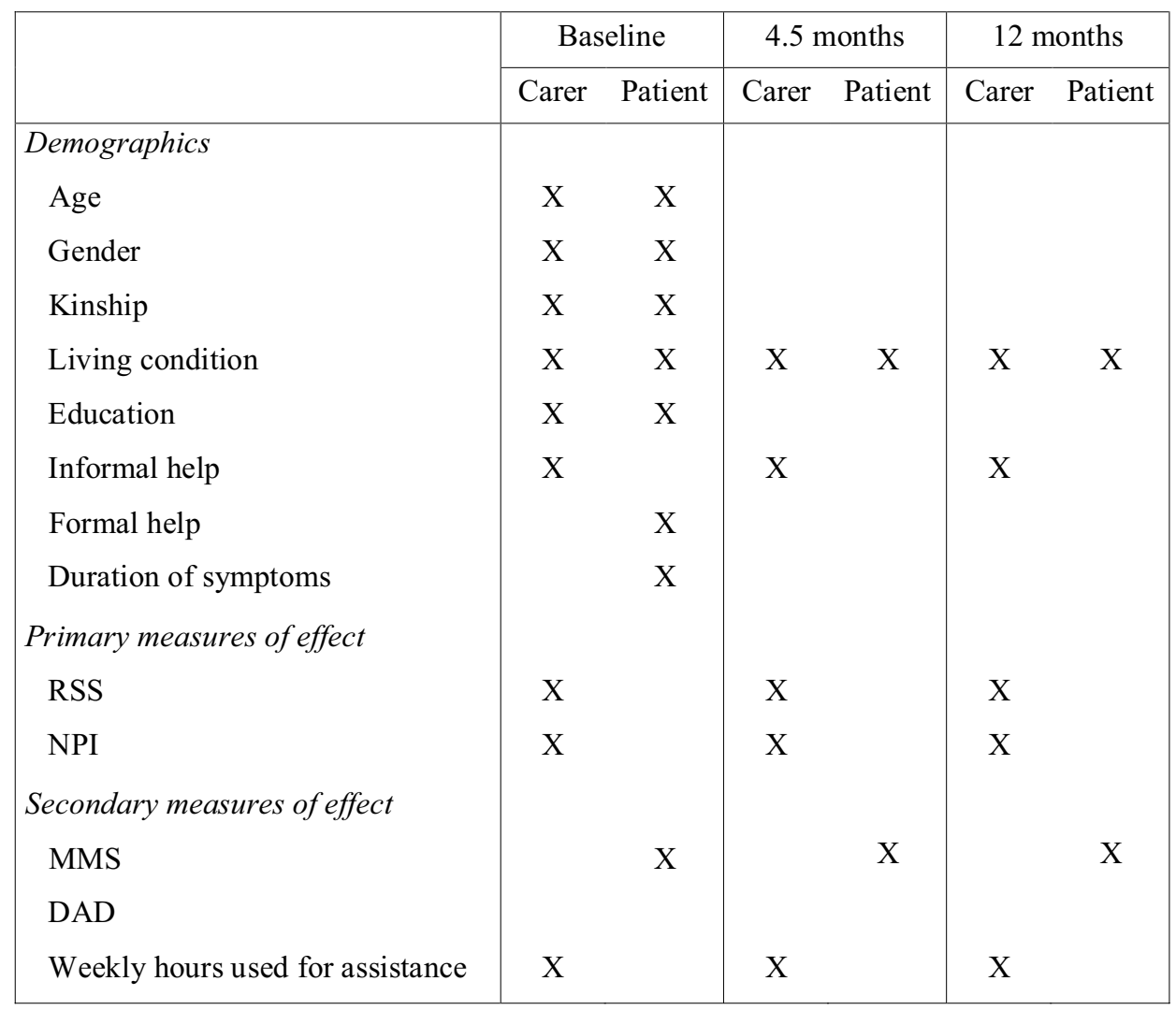

\subsection{The intervention}

The intervention consisted of two elements. The first element was a three-hour educational programme about dementia run by a medical doctor (a geriatrician or psychiatrist). The carers were informed about symptoms of dementia and the normal course of the disorder, pharmacological and non-pharmacological treatment. A treatment manual consisting of two power-point presentations, one about dementia and one about groups for carers, including the 
problem-solving method, were used by the lecturers to achieve reliability concerning the educational part of the intervention. In addition, the carers received hand-outs from the lecturers and two booklets;

- 'Hva er demens' (What is dementia) (Brækhus et al., 2002) giving a short overview of symptoms of dementia, diagnosis and treatment.

- 'Å leve med demens - en handbook for pårørende' (To live with dementia, a handbook for carers) (Dahl, 2000) with advices about how to solve general problems that carers may face.

The second element was six group meetings each of two hours duration to learn communication skills and structured problem solving (see Textbox 1).

Textbox 1. Structured problem solving

1. Definition of a problem (as concrete as possible)

2. Brainstorming; all proposals to be recorded

3. Discussing the proposed solutions pro and con

4. Choosing a solution or a combination of solutions

5. Detailed preparation of how to carry out the chosen solution

6. Evaluation at next meeting

The group leaders were five psychiatric and two geriatric nurses with longstanding experience within the field of dementia. Before starting the intervention, the group leaders took part in a training seminar so as to learn about the method. Role-play was used to train them in how to perform problem solving. The group leaders were supervised by the author throughout the study in regular meetings, workshops and seminars. Telephone conferences were also used as some of the participating centres were located in other parts of Norway. We did not have the necessary equipment or capacity to taperecord or videotape the group sessions. Therefore, the group leaders wrote a report after each meeting. The problem solving sheets (see Textbox 1) were also kept.

The group leader was the administrative leader, i.e. responsible for preparing the group room with respect to equipment (table, chairs, and flip-charts) and keeping to the time schedule. The group meetings started with a few minutes 'small talk' before evaluating the problem solving from the last meeting. The group leader took responsibility for unsuccessful problem 
solving. Possible reasons for failure could be insufficient exploration of the problem or inappropriate planning of how to carry out the chosen solution. Then a new problem to explore was chosen from among the problems the group members were struggling with. The group leader was recommended to focus on problems that were of interest to all the participants, or at least most of them. Figure 2 shows the structure of the group meeting.

Figure 2. Structure of the group meetings (modified from Øksnevad et al., 2000)

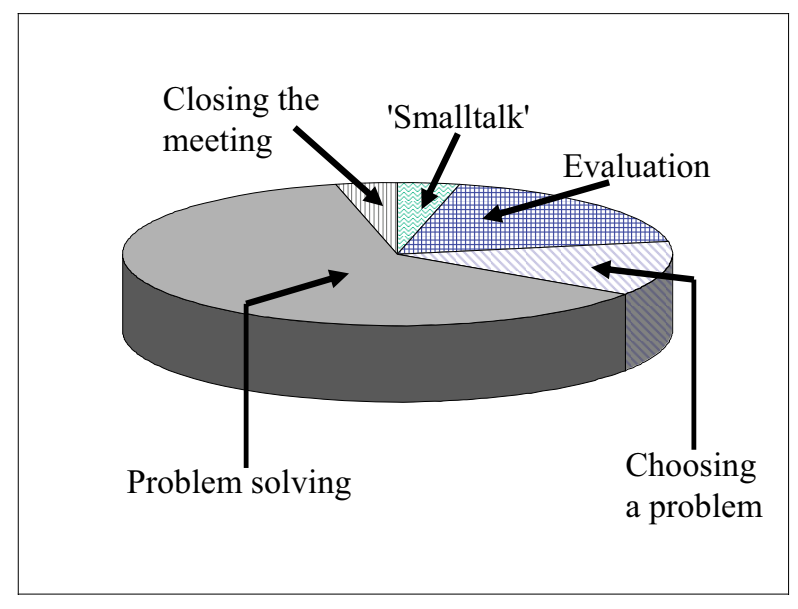

The most common problems discussed in the groups were about how to handle neuropsychiatric symptoms, how to get more informal and formal assistance and how to make the patient accept help. Cognitive techniques (James et al., 2001) were used to make the carers understand that undesirable behaviour is part of the dementia syndrome, and to help them to obtain more realistic expectations concerning the patient's functioning in everyday life.

To foster the group cohesion there was only a fortnight between the seminar and the two first group meetings. Then we gradually increased the number of weeks between the group meetings to give the carers more time to try out new ways of problem solving, see Table 7. 


\subsection{Control condition}

The control group was offered treatment as usual, i.e. consultations at the memory clinic every four to six months and ad hoc counselling when needed.

The time schedule of the intervention with respect to distribution of the group meetings and assessments for the intervention group as well as the control group are reported in Table 7.

Table 7. Time schedule

\begin{tabular}{|l|ccccccc|c|c|}
\hline & Week 0 & Week 2 & Week 4 & Week 7 & Week 10 & Week 14 & Week 18 & 4.5 months & 12 months \\
\hline $\begin{array}{l}\text { Intervention } \\
\text { group } \\
\text { - baseline }\end{array}$ & Seminar & $\begin{array}{l}\text { 1. group } \\
\text { meeting }\end{array}$ & 2. group & 3. group & 4. group & 5. group & 6. group \\
meeting & meeting & meeting & meeting & $\begin{array}{l}\text { Retesting } \\
\text { of carers }\end{array}$ & $\begin{array}{c}\text { Retesting } \\
\text { of patients } \\
\text { and carers }\end{array}$ \\
\hline $\begin{array}{l}\text { Control } \\
\text { group } \\
\text { - baseline }\end{array}$ & Patients and carers - treatment 'as usual' & & & & $\begin{array}{l}\text { Retesting } \\
\text { of carers }\end{array}$ & $\begin{array}{l}\text { Retesting } \\
\text { of patients } \\
\text { and carers }\end{array}$ \\
\hline
\end{tabular}

\subsection{Ethics}

The Regional Committee for Ethics in Medical Research in Eastern Norway and the Norwegian Data Inspectorate approved the project. The participants, both patients and carers, received oral and written information and gave written consent to participate.

\subsection{Statistics}

The statistical analyses were performed with the SPSS-13.0 programme (Papers I and II) and SPSS-14.0 (Papers III and IV). Two-tailed $t$-tests, or Mann-Whitney tests when appropriate, were used to compare continuous and dichotomous carer and patient variables. Chi-square tests were applies to compare dichotomous variables, whereas Spearman rank correlation was used to explore the relationship between ordinal outcome variables and continuous or ordinal variables. Factor analysis of the Relatives' Stress Scale (RRS) was performed using principal component analysis with varimax rotation. Bivariate and multivariate associations between dependant and potential explanatory variables were explored by means of linear regression. Strongly skewed variables were logarithmically transformed before they were entered into the regression analyses. Goodness-of-fit of the models was assessed by residual 
plots (Altman, 1992). Logistic regression analysis was carried out for multivariate analyses of dichotomised outcome variables. Continuous and ordinal explanatory variables were divided into quintiles, and their linear associations with the outcomes were then evaluated according to the recommendations to be found in Hosmer and Lemeshow (1989). Explanatory variables demonstrating a non-linear relation with the outcomes were dichotomized.

Two-steps cluster analysis was performed to separate carers with low, medium-high and high risk of psychiatric morbidity. The characteristics of these three groups were compared by means of one-way ANOVA. Calculations of sensitivity, specificity, accuracy, and likelihood ratio for a positive test ( $\mathrm{LR}+$ ) were performed to find the best cut-points for the RSS. The results were visualized by means of Receiver Operating Characteristic (ROC) curves. The discriminatory power between the three groups was calculated according to the following formula:

Discriminatory power $=\frac{\text { Mean } 2-\text { Mean } 1}{1 / 2(\text { SD } 1+\text { SD } 2)}$

A discriminatory power of 0.5 or higher is usually of clinical interest, and a value above 0.8 is considered to be high (Charlin et al., 2006).

According to a power analysis at least 180 carer/patient dyads should be included in the intervention study. All participants who were assessed at baseline were included in the intention-to-treat efficacy analysis. Last-observation-carried-forward method (LOCF) as well as the observed-cases method (OC) was used. Two-tailed $t$-tests were used when comparing outcome variables for normally distributed data and two-tailed Mann-Whitney $U$ tests for skewed data and subgroups with few participants. Chi-square tests were used to compare dichotomous variables. Linear mixed model analyses were also applied in order to adjust for possible differences between groups. These analyses did not alter the results and are not reported. 
Table 8 Overview over statistics used in the papers

\begin{tabular}{|c|c|c|c|}
\hline Paper I & Paper II & Paper III & Paper IV \\
\hline $\begin{array}{l}\text { Principal component } \\
\text { analysis of the RSS. } \\
\text { Bivariate and } \\
\text { multivariate linear } \\
\text { regression analysis of } \\
\text { total RSS and the } \\
\text { three RSS subgroups } \\
\text { emotional distress, } \\
\text { social distress and } \\
\text { negative feelings as } \\
\text { dependant variables. }\end{array}$ & $\begin{array}{l}\text { Two-step cluster } \\
\text { analysis, ANOVA. } \\
\text { Estimating } \\
\text { sensitivity, } \\
\text { specificity, accuracy } \\
\text { and LR+ of the } \\
\text { identified risk groups. } \\
\text { ROC-curve. }\end{array}$ & $\begin{array}{l}\text { Spearman rank } \\
\text { correlation and two- } \\
\text { tailed } t \text {-tests or Mann- } \\
\text { Whitney tests to } \\
\text { explore bivariate } \\
\text { associations. } \\
\text { Bivariate and } \\
\text { multiple logistic } \\
\text { regression analysis } \\
\text { to explore the } \\
\text { association between } \\
\text { the dichotomous } \\
\text { outcome variables } \\
\text { intrusion, avoidance } \\
\text { and the combined } \\
\text { variable (intrusion } \\
\text { and avoidance }>8 \text { ). }\end{array}$ & $\begin{array}{l}\text { Power analysis. } \\
\text { LOCF-analysis and } \\
\text { OC-analysis. } \\
\text { Two tailed } t \text {-test to } \\
\text { compare the IG and } \\
\text { the CG and when } \\
\text { performing the } \\
\text { subgroup analysis. }\end{array}$ \\
\hline
\end{tabular}




\subsection{Abstracts of the papers included in the thesis}

Paper I

\section{Objective}

To identify carer and patient characteristics associated with various aspects of burden of care.

\section{Methods}

The burden on 196 carers, each caring for one patient with dementia, was rated by means of the Relative Stress Scale (RSS). Patients were assessed with the Mini Mental State Examination (MMSE), the Disability Assessment for Dementia (DAD) and the Neuropsychiatric Inventory (NPI).

\section{Results}

Factor analysis of the RSS resulted in three subgroups: 'emotional distress ', 'social distress' and 'negative feelings'. The total NPI score contributed to the explanation of the RSS total score and the three RSS subgroup scores with an explanatory power of $37 \%$ for total RSS, $34 \%$ for emotional distress, $27 \%$ for social distress and $20 \%$ for negative feelings. In multiple regression analysis, total NPI, DAD\%, the carer being a wife and the hours spent caring per week, contributed to the explanation of total RSS with an explanatory power of 48 $\%$. Total NPI, the carer being a female and the hours spent caring, explained $38 \%$ of the variance in 'emotional distress'. Total NPI, the DAD\%-score, contact with the patient on a daily basis and the hours spent caring, explained 'social distress' (49\%). 'Negative feelings' were associated with total NPI, younger patients and the carer being a wife (27\%).

\section{Conclusion}

The RSS offers an opportunity to differentiate between different patterns of distress. This facilitates the creation of tailored intervention to reduce the strain of caring. 
Paper II

\section{Objective}

To compare the scores on the Relatives' Stress Scale (RSS) with those on the General Health Questionnaire (GHQ) and the Geriatric Depression Scale (GDS), and to establish a cut-point score for RSS in order to distinguish carers with symptoms of psychiatric disorders from those without.

\section{Methods}

One hundred and ninety-four carers of 194 patients suffering from dementia according to ICD-10 were included in the study. Burden of care was assessed by the 15 -items RSS, and psychiatric symptoms by means of the GHQ-30 and the 30-items GDS. A case score above 5 on GHQ and above 13 on GDS were used to define carers with probable psychiatric morbidity. Sensitivity (SS), specificity (SP), accuracy and likelihood ratio for a positive test $(\mathrm{LR}+)$ were calculated for different cut-points of the RSS.

\section{Results}

Fifty-six per cent of the carers had a GHQ score above 5, and $22 \%$ had a GDS score above 13. A two-step cluster analysis using 192 of the 194 carers, identified three groups of carers; a low risk group for psychiatric morbidity (LRG), 82 carers with GHQ $<5$ and GDS $<13$; a medium risk group (MRG), 69 carers with GHQ $>5$ and GDS $<13$; and a high-risk group (HRG), 40 carers with GHQ $>5$ and GDS $>13$. The optimal RSS cut-point to distinguish between the LRG and the others was $>23$ (SS 0.72, SP 0.82, accuracy 0.76, LR+ 4.0), whereas the optimal cut-point to separate the HRG from the others was $>30$ (SS 0.74, SP 0.87 , accuracy $0.84, \mathrm{LR}+5.7)$.

\section{Conclusion}

The RSS is a useful instrument to stratify carers according to their risk of psychiatric morbidity. 
Paper III

\section{Aims}

To explore intrusion and avoidance in family carers of dementia patients.

\section{Method}

We studied 196 family carers of 196 home-dwelling dementia patients. Carers were assessed by the Impact of Events Scale (IES), the Geriatric Depression Scale (GDS), the State Trait Anxiety Inventory (STAI) and the Distress scale of the Neuropsychiatric Inventory (NPI-D), and patients with the Mini Mental State Examination (MMSE), the Disability Assessment for Dementia (DAD), and the Neuropsychiatric Inventory (NPI).

\section{Results}

Twenty carers $(10 \%)$ scored above 19 on the intrusion and avoidance subscales of the IES, whereas $90(47 \%)$ scored above 8 on both subscales. This moderate to high stress response was independently explained by being a spouse (OR 3.74 (95\% CI $1.81-7.74)$ ), high scores on GDS (OR 1.12 (95\% CI 1.06 - 1.18) per unit increase) and high score on NPI-D (OR 1.05 (95\% CI 1.01-1.09) per unit increase).

\section{Conclusions}

Family carers of patients with dementia experience moderate to high levels of intrusion and avoidance. 
Paper IV

\section{Objective}

To identify the characteristics of carers and patients who responded positively to a short-term psychosocial intervention programme for family carers of patients with dementia.

\section{Methods}

The study was a multi-centre randomised controlled trial (RCT). Carers of 180 patients suffering from dementia recruited at seven Memory Clinics at Geriatric or Psychiatric Departments participated in the study. Carers of the intervention-group were educated about dementia and in six group-meetings taught how to use structured problem-solving. The control-group received "treatment as usual". The effect on patients was measured with the Neuropsychiatry Inventory (NPI), and on carers with the Relatives' Stress Scale (RSS).

\section{Results}

The intention-to-treat efficacy analysis included 171 carer/patient dyads. The intervention did not have any effect on the primary outcome variables. The burden measured by the RSS, increased in both groups; however, more carers of the control group converted from a low burden group to a medium or high burden group after 4.5 months. In a subgroup analysis we found a statistically significant difference in the NPI-score in favour of the intervention group among female patients.

\section{Conclusion}

Our results indicate that the extent of burden as well as the patients' gender should be considered when creating interventions for carers. 


\subsection{Discussion of the main results}

\subsection{The cross-sectional studies}

The self-administrated RSS covers various aspects of burden such as subjective emotional responses, restrictions on the carers' social lives, and negative feelings associated with the patients and their behaviour. Except for one item (difficulties having visitors), the result of the factor analysis turned out to be identical with the one performed by Greene et al. 20 years ago in Britain, showing the usefulness of the scale over time and across cultures. As we used other scales to assess the patients' ADL-impairment and BPSD, we were not able to replicate the other findings done by Greene et al. However, our choice to use newer developed scales to study BPSD and ADL seem more appropriate, as this opened up an option to compare our results with results from up-to-date studies.

In accordance with most studies within this field (Teri, 1997; Donaldson et al., 1997; Kaufer et al., 1998; Clyburn et al., 2000; Gaugler et al., 2005, Mahoney et al., 2005; Marvardi et al., 2005; Rinaldi et al., 2005), we found that the neuropsychiatric symptoms of the patients was the most important factor contributing to the burden of care and distress as measured by RSS and the RSS subscales. Additionally, the time used for assisting and helping the patients contributed as an important explanatory factor for emotional and social distress. There was a large variation among carers in their reports of the number of hours spent caring per week, and we found a relatively high correlation between the reported time used for caring and the patients' ADL-impairment $(\mathrm{R}=-0.45, \mathrm{p}<0.001)$. The high association between the time spent caring and social distress was an expected finding, as carers needing more time to look after, assist and help patients with impaired ADL function usually will feel more restricted in their social life. The high correlation between time spent caring and emotional distress may have to do with the fact that carers who are spending more time together with the patient are more exposed to the patients' disruptive behaviour, which represents the main reason for emotional distress.

The association between negative feelings and time spent caring $(R=0.19, p=0.009)$, disappeared in the multivariate analysis. The occurrence of neuropsychiatric symptoms was a stronger explanatory variable.

The multivariate analyses showed that female carers were more emotionally distressed than male carers, a finding in accordance with most of the research done on the carers' burden 
(Morris et al., 1991; Almberg et al., 1998; Gallicchio et al., 1998; Bedard et al., 2005). The finding that spouses and other family carers having daily contact with the patient reported more social distress is easy to interpret. A high score on RSS-social distress was associated with higher scores on the NPI, increased ADL-impairment and more time spent caring, which leads to more restrictions on the carer's daily life.

In view of the high prevalence of clinically significant distress in the carers, it is tempting to abandon the concept of burden and instead focus on possible psychiatric morbidity in the carers (George and Gwyther, 1986; Black and Almeida, 2004). However, carers visited the doctors at the memory clinics to get a diagnosis for their cognitively impaired family member, not to be diagnosed themselves. Offering the carers a psychiatric examination would probably be seen as an offence. Therefore, it seems more appropriate and probably clinically more useful, to use a burden scale that focuses on general problems connected with the caring role as a screening instrument of psychiatric morbidity. The RSS seems to have such properties

By the use of GHQ-30 and GDS as benchmarks it was possible to estimate cut-point scores for the RSS for probable psychiatric morbidity (RSS $>23$ ) and probable depression (RSS $>30$ ). We were able to separate three groups of carers with low, intermediate and high risk of suffering from a psychiatric condition, respectively. The groups differed not only in their RSS, GHQ and GDS scores, but also in the patients' NPI scores. These findings are in accordance with several other studies reporting that disturbed behaviour of the patients is a risk factors for depression and other psychiatric conditions in the carers (Donaldson et al., 1997; Teri, 1997; Dunkin and Anderson-Hanley, 1998; Bedard et al., 1997; Burns, 2000, Clyburn et al., 2000; Rinaldi et al., 2005; Mahoney et al., 2005), and justifies the use of GHQ and GDS as markers of possible psychiatric morbidity and depression when calculating cut-points for the RSS. According to the estimated cut-point values of RSS published in Paper II, about $50 \%$ of the carers reported distress of possible clinical significance and $27 \%$ a probable depression. This prevalence of psychiatric morbidity is in agreement with results of other studies and reviews (Ballard et al., 1995; Schulz et al., 1995; Teri, 1997), which also support the validity of the estimated cut-points. Since the carers received no formal diagnosis through a psychiatric interview, the estimates of the sensitivity and specificity must be interpreted with this limitation in mind. Although GHQ and GDS are robust and well- 
established scales, they cannot replace a psychiatric diagnosis. In conclusion, Study II should be replicated with a psychiatric assessment in addition to self-administration questionnaires.

Almost 50 per cent of the carers reported moderate to high levels of intrusion and avoidance, consistent with a moderate to high stress response. Higher levels of intrusion and avoidance (scores above 8) were associated with higher levels of distress due to the patients' neuropsychiatric symptoms. The patients of these distressed carers were often more disabled in their ADL-performance and in need of more help and assistance than patients being cared for by less distressed carers. Although a high score on the NPI and impaired ADL performance were significantly associated with the stress responses in the bivariate analysis, these variables did not remain of statistical significance in the multivariate analyses. Spouses and carers living together with the patient spend more time face-to-face with the patient, and are thereby more exposed to the symptoms of dementia. Spouses seem to be more likely to use avoidance as a coping strategy to reduce the distressing intrusive feelings and thoughts. However, as they are steadily exposed to the psychiatric symptoms and disruptive behaviour of the patients, more avoidance must be used to control or reduce intrusion. Higher levels of intrusion and avoidance are associated with higher levels of anxiety and depression. We may, therefore, assume that carers with high scores on intrusive feelings and avoidance are in need of treatment that can reduce anxiety and depression. This can be achieved by use of cognitive-behavioural techniques (CBI). The carers have to learn how to modify catastrophic thinking and how to analyse troublesome situations instead of avoiding thinking about them.

\subsection{The intervention study}

Successful interventions within this field of research have been relatively time-consuming and required highly trained therapists such as psychologists and health professionals with at least a master's degree (Mittelsman et al., 1996). However, most health professionals in Norwegian municipalities are either nurses or nursing assistants, and no financial resources have up to now been allocated to support programmes for carers. Thus, there has been a need to evaluate whether a simple and cheap short-term PSI programme could be effective.

We were not able to demonstrate any effect of the intervention on the primary outcome variables; the total RSS score and the total NPI score in the 12-month follow-up period. However, in the subgroup analysis we found a statistically significant difference in total NPI 
score in favour of the intervention group among female patients. The carers of the female patients were husbands and adult children, of whom daughters represented the majority.

The stabilisation of BPSD in the intervention group could be explained by the fact that female patients are easier to handle than male patients (Bedard et al., 2005). The gender differences in ways of coping (Parks and Pilisuk, 1991; Corcoran, 2002) may explain why male carers (husbands) seem to respond to the problem-solving approach of the study. When it comes to the adult children who predominantly were daughters, we could assume, or at least speculate, that they have different approach to the carer role than wives have. It is also possible that daughters in accordance with the findings of Graham et al. (1997), through the group discussions, have gained more realistic expectations about the functioning of their female family member with dementia and were taught how to respond to BPSD in a more appropriate way. It would have been of interest to explore this hypothesis, because it has practical implications for the tailoring of future educational programmes for various family members of patients with dementia.

The increase in the NPI score of female patients in the control group was not followed by an increase in the RSS score among the carers (spouses and daughters), a somewhat surprising result, as BPSD is the most important factor contributing to the burden of care. The explanation could possibly be that husbands will gradually take over household chores as the illness progresses and thereby fill their days of retirement with meaningful tasks, whereas adult children will often function as care managers (Brodaty and Green, 2002), organizing the necessary professional help and assistance for the sick family member. Still, husbands as well as adult children may feel more restricted in their everyday life as the dementia progresses, which to some extent may explain the lack of effect when it comes to the burden of care. If that is the case, respite care and daycentre care would be valuable additional services that should be combined with PSI in order to reduce the burden of care and postpone nursing home placement.

The reason why we did not find any positive change in the NPI scores among male patients or change in the RSS scores in their female carers in the intervention group (predominantly wives) could be related to the female way of coping (Fitting et al., 1986). The intervention may not have met the wives' needs to focus on the emotional aspects of their carer role. Another possible explanation for the differentiated response according to carer's gender 
could be that females are more used to the carer role. The wives may intuitively know how to handle the patient and, thus, are not in need of any education about dementia, or have little to learn from the problem-solving approach that was offered in this study. The female carers, in contrast to males, may also perform more personal care tasks such as toileting and bathing (Miller and Cafassio, 1992), tasks that often result in conflict and increased levels of burden. This fits well with the observation that the female carers of the male patients reported a higher level of burden according to the RSS throughout the study, a finding that is in accordance with other studies (Zarit et al., 1986; Vitaliano et al., 1991; Bedard et al., 2005).

When dividing the carers into three groups according to their score on the RSS at baseline, we found a significant difference between the intervention and control group at 4.5 months follow-up. This difference disappeared at 12 months. The reason for this finding is probably that some carers in the intervention group only managed to use problem solving as long as they participated in the group. The duration of the intervention was probably too short or the intensity too low to enable them to use the problem-solving method when facing new problems due to the deterioration of the patient's condition. A longer intervention period with meetings every fortnight may therefore be a more appropriate approach. Another explanation could be that carers of patients with dementia are in need of a supporting person all the way as dementia progresses. It might be that the group leaders were recognised as such a supporting person.

Forty-one carers in the intervention group had an RSS score higher than 23 at baseline, consistent with a moderate to high risk of psychiatric morbidity. The intervention did not have any effect on the burden of these carers. As problem solving was the main therapeutic tool in the limited number of group sessions, it is questionable whether the most distressed carers were able to benefit from this approach. Retrospectively, it would probably have been better to offer the carers in the intervention group with a high score on the burden scale (RSS) a limited number of structured individual counselling sessions before entering the problem-solving group, in accordance with the approach described by Mittelman et al., (1993). Another explanation for the results of this study was the choice of measure of efficacy. To test the problem-solving capacity of the carers before and after the intervention could have been an adequate approach. 


\subsection{Limitations}

\subsubsection{Subjects}

On the one hand, the data came from a selected group of patients and carers recruited from memory clinics and thus not representative of the entire non-institutionalised population of dementia patients and carers. The multi-site design with patients recruited from clinics in departments of geriatric medicine and old-age psychiatry from both rural and urban areas has, on the other hand, offered us a wide spectrum of patients and carers, which may allow generalisation.

Compared with the prevalence of dementia by gender, male patients were overrepresented in the study (Engedal and Haugen, 2004). There may be several reasons for this. One explanation could be that male patients are more difficult to handle and therefore sooner referred to a memory clinic. Another explanation could be that elderly females are more prone to ask for help for their husbands than elderly male persons, and as seen in this study wives reported higher levels of burden, emotional distress and negative feelings towards the patient than the husbands. The wives may therefore have been more motivated than husbands to join a study like this.

The selection of carers highly motivated to participate in the study may also have introduced a bias.

\subsubsection{Assessments}

Most of the assessment instruments used in the study are robust and well-established scales used in daily clinical practice and in research. Still, the fact that we exclusively relied on self-report questionnaires when assessing the carers' situation may perhaps represent a weakness of the study. Assessment by a psychiatrist would have given us better ratings and an opportunity to obtain a formal psychiatric diagnosis. The use of self-report questionnaires and the indirect evaluation of patients through proxy interviews may also have resulted in underreporting of symptoms in patients due to a wish to protect the patient or to give an impression of being in control of the situation. Through the intervention the carers may have learned to be more open about how they feel, resulting in more realistic and higher ratings of burden and distress after the intervention (Farran and Keane-Hagarty, 1994). However, this theory is impossible to test. 


\subsubsection{Statistical power of the intervention study}

The intention was to include enough carers to be able to conduct subgroup analysis. Using information from comparable earlier studies we therefore made a power analysis before the intervention study started. According to this analysis 180 patients/carers dyad should be included. It turned out that the included sample was heterogenic with respect to carer characteristics as well as patient properties, leading to a low power when performing the subgroup analysis. It would have been better to include only one selected group of carers, for instance spouses.

When working with therapeutic groups in ordinary clinical practice, there are "rules" to be followed that is impossible to obtain when performing a controlled randomised study. According to these rules the group shall be balanced with respect to the participants' gender, age and kinship to the patients. To prevent isolation of any group member it is also advisable that at least two group members have the same kind of problems. In our study this was impossible to obtain because of the wide inclusion criteria and the method of randomisation. Stratification may therefore have been a better procedure for the selection of participants in the intervention study.

\subsubsection{Training of the research assistants and group leaders}

Although all research assistants and group leaders received the same training, there could possibly be some disagreement between raters when evaluating the patients. We did not carry out an inter-rater agreement study. This could have been done to secure high reliability.

Only one group leader was previously trained in the psycho-educational approach used in the study. The other group leaders had experience in psychodynamic supportive approaches. The group leaders sometimes had difficulty in accomplishing the problem-solving method. It is possible that a more intensive and lengthier training is required to pick up the problem solving method properly. However, we do not believe that this fact influenced the results of the study significantly. 


\subsection{Conclusions}

The main results of this study show that it is strenuous to be a family carer of a person suffering from dementia, even when the patient is in an early stage of the disorder. BPSD is the most important patient factor contributing to the burden of care.

The RSS can be a useful instrument to investigate different aspects of the burden of care and thereby enable us to tailor interventions to the individual carer/patient dyad. The cut-point score on the RSS can be of help. With increased levels of burden we observed an increased risk of psychiatric morbidity, mainly depression and anxiety.

Higher levels of intrusion and avoidance were revealed, and these two reactions were associated with depressive and anxiety symptoms, especially in spouses and carers having daily contact with the patient. Due to the expected long-lasting exposure to the stressors, it is important to tailor flexible intervention to be able to meet the changing needs of the carer as well as the patient throughout the course of dementia.

Our results indicate that wives, husbands and non-spouses should be offered different intervention programmes. Wives of patients suffering from dementia will probably benefit from an individual cognitive approach, especially when they are distressed to a clinical level, whereas education and problem solving may be beneficial for non-spouses and husbands. The results of the intervention study further underline the need for flexible and longer-lasting intervention in accordance with the recommendations of the latest reviews and meta-analysis (Brodaty et al., 2003, Pinquart and Sörensen, 2006). 


\subsection{Future research}

As the factor analysis of the RSS was performed on carers of patients with predominantly mild dementia, the factor analysis should be repeated with carers of patients covering all stages of dementia as well as carers scoring from zero to 60 on the RSS. To control the validity of the established cut-points for the RSS, a study should be conducted with a psychiatric interview as the benchmark. When it comes to the study on the specific stress responses, this study should be repeated with the revised version of the Impact of Event Scale (IES-R) (Weiss and Marmar, 1997), which would enable us to study the relevance of PTSD in carers of patients with dementia. A longitudinal study would also give us greater insight into factors that increase, maintain or modify the stress responses of the carers.

Regarding the intervention study, it seems as if daughters and husbands benefit from participating in problem-solving groups, whereas the wives are in need of another approach. Maybe cognitive behavioural therapy (CBT) would be more appropriate for this group. However, we still do not know whether they would benefit more from an individual approach or CBT in a group setting. 


\section{References}

Almberg B, Jansson W, Grafstrom M, Winblad B. 1998. Differences between and within genders in caregiving strain: a comparison between caregivers of demented and noncaregivers of non-demented elderly people. J Adv Nurs 28: 849-58.

Altman DG. 1999. Practical Statistics for Medical Research. Chapman \& Hall/CRC, Boca Raton, Florida.

Akkerman RL, Ostwald SK. 2004. Reducing anxiety in Alzheimer's disease family caregivers: the effectiveness of a nine-week cognitive-behavioral intervention. $\mathrm{Am} \mathrm{J}$ Alzheimers Dis Other Demen 19:117-23

American Psychiatric Association. 1994. Diagnostic and Statistical Manual of Mental Disorders (4th edn) (DSM-IV). Washington, DC: APA.

Anthony-Bergstone CR, Zarit SH, Gatz M.1988. Symptoms of psychological distress among caregivers of dementia patients. Psychol Aging 3: 245-48.

Ballard CG, Saad K, Coope B, Graham C, Gahir M, Wilcock GK, Oyebode F. 1995. The aetiology of depression in the carers of dementia sufferers. $J$ Affect Disord 35: 59-63.

Baumgarten M, Battista RN, Infante-Rivard C, Hanley JA, Becker R, Gauthier S. 1992. The psychological and physical health of family members caring for an elderly person with dementia. J Clin Epidemiol 45: 61-70.

Bedard M, Molloy DW, Pedlar D, Lever JA, Stones MJ. 1997. IPA/Bayer Research Awards in Psychogeriatrics. Associations between dysfunctional behaviors, gender, and burden in spousal caregivers of cognitively impaired older adults. Int Psychogeriatr 9: 277-90.

Bedard M, Molloy DW, Pedlar D, Lever JA, Stones MJ. 2000. Burden in caregivers of cognitively impaired older adults living in the community: methodological issues and determinants. Int Psychogeriatr 12: 307-32. 
Bedard M, Molloy DW, Squire L, Dubois S, Lever JA, O'Donnell M. 2001. The Zarit Burden Interview: a new short version and screening version. Gerontologist 41: 65257.

Bedard M, Kuzik R, Chambers L, Molloy DW, Dubois S, Lever JA. 2005. Understanding burden differences between men and women caregivers: the contribution of carerecipient problem behaviours. Int Psychogeriatr 17: 99-118.

Birks J. 2006. Cholinesterase inhibitors for Alzheimer's disease. Cochrane Database Syst Rev 1: CD005593.

Black W, Almeida OP. 2004. A systematic review of the association between the Behavioral and Psychological Symptoms of Dementia and burden of care. Int Psychogeriatr 16: 295-315.

Bledin KD, MacCarthy B, Kuipers L, Woods RT. 1990 Daughters of people with dementia. Expressed emotion, strain and coping. Br J Psychiatry 157: 221-27.

Boye B, Malt UF. 2002. Stress response symptoms in relatives of acutely admitted psychotic patients: a pilot study. Nordic J Psychiatry 56: 253-60.

Braekhus A, Oksengard AR, Engedal K, Laake K.1998. Social and depressive stress suffered by spouses of patients with mild dementia. Scand J Prim Health Care 16: 242-46.

Braekhus A, Dahl TE, Engedal K, Laake K. 2002. Hva er aldersdemens? Nasjonalt kompetansesenter for aldersdemens og Hukommelsesklinikken Ullevål universitets sykehus. Sem.

Brink TL, Yesavage JA, Lum O, Heersms PH, Adey M, Rose TL. 1982. Screening tests for geriatric depression. Clin Gerontologist 1: 37-43.

Brodaty H, Gresham M. 1989. Effect of a training programme to reduce stress in carers of patients with dementia. BMJ 299: 1375-79. 
Brodaty H, Hadzi-Pavlovic D. 1990. Psychosocial effects on carers of living with persons with dementia. Aust N ZJ Psychiatry 24: 351-61.

Brodaty H, McGilchrist C, Harris L, Peters KE. 1993. Time until institutionalization and death in patients with dementia. Role of caregiver training and risk factors. Arch Neurol 50: 643-50.

Brodaty H, Gresham M, Luscombe G. 1997. The Prince Henry Hospital dementia caregivers' training program. Int J Geriatr Psychiatry 12: 183-92.

Brodaty H, Green A. 2000. Family carers for people with dementia. In O'Brien J, Ames D, Burns A (eds) Dementia (2nd ed) London, Arnold.

Brodaty H, Green A, Koschera A. 2003. Meta-analysis of psychosocial interventions for caregivers of people with dementia. J Am Geriatr Soc 51:657-64.

Brown GW, Birley JLT, Wing JK. Influence of family life on the course of schizophrenic disorder: replication. Br J Psychiatry 1972; 121: 241-58.

Burns, A. 2000. The burden of Alzheimer's disease. Int J Neuropsychopharmacol 3: 31-38.

Burns A, Rabins P. 2000. Carer burden dementia. Int J Geriatr Psychiatry 15 Suppl 1: 9-13.

Charlin B, Gagnon R, Pelletier J, Coletti M, Abi-Rizk G, Nasr C, Sauve E, van der Vleuten C. 2006 Assessment of clinical reasoning in the context of uncertainty: the effect of variability within the reference panel. Medical Education 40: 848-54.

Clyburn LD, Stones MJ, Hadjistavropoulos T, Tuokko H. 2000. Predicting caregiver burden and depression in Alzheimer's disease. J Gerontol B Psychol Sci Soc Sci 55: 2-13.

Cooper C, Balamurali TBS, Livingston G. 2007. A systematic review of the prevalence and covariates of anxiety in caregivers of people with dementia. Int Psychogeriatr 19: 175-95. 
Corcoran MA. 1992. Gender differences in dementia management plans of spousal caregivers: implications for occupational therapy. Am J Occup Ther 46: 1006-12.

Courtney C, Farrell D, Gray R, Hills R, Lynch L, Sellwood E, Edwards S. 2004. Long-term donepezil treatment in 565 patients with Alzheimer's disease (AD2000): randomised double-blind trial. Lancet 363: 2105-15.

Covinsky K, Newcomer R, Fox P, Wood J, Sands L, Dane K, Yaffe K. 2003. Patient and caregiver characteristics associated with depression in caregivers of patients with dementia. J Gen Intern Med 18: 1006-14.

Cummings JL. 1997. The Neuropsychiatric Inventory: assessing psychopathology in dementia patients. Neurology 48: 10-16.

Dahl TE. 2000. Demens - en håndbok for pårørende. Nasjonalforeningen for folkehelsen. Falch as.

Davis KL, Marin DB, Kane R, Patrick D, Peskind ER, Raskind MA, Puder KL.1997. The Caregiver Activity Survey (CAS): development and validation of a new measure for caregivers of persons with Alzheimer's disease. Int J Geriatr Psychiatry 12: 978-88.

Deimling GT, Bass DM, Townsend AL, Noelker LS.1989. Care-related stress. A comparison of spouse and adult-child caregivers in shared and separate households. J Aging Health 1: 67-82.

Depp C, Sorocco K, Kasl-Godley J, Thompson L, Rabinowitz Y, Gallagher-Thompson D. 2005. Caregiver self-efficacy, ethnicity, and kinship differences in dementia caregivers. Am J Ger Psychiatry 13:787-94.

Donaldson C, Tarrier N, Burns A. 1997. The impact of the symptoms of dementia on caregivers. Br J Psychiatry 170: 62-68.

Dunkin JJ, Anderson-Hanley C. 1998. Dementia caregiver burden: a review of the literature and guidelines for assessment and intervention. Neurology 51: 53-60. 
Edhag O, Norlund A. 2006. Dementia diseases - a systematic review. SBU's summary and conclusions. Lakartidningen 103: 2135-39.

Engedal K, Gilje K, Laake K. 1988. Prevalence of dementia in a Norwegian sample aged 75 years and over and living at home. Compr Gerontol 2: 102-06.

Engedal K, Haugen PK. 1993. The prevalence of dementia in a sample of elderly Norwegians. Int J Geriatr Psychiatry 8: 565-70.

Engedal, K. 2002. Diagnosis and treatment of dementia. Tidsskr Nor Laegeforen 122: 52024.

Engedal K, Haugen PK. 2004. Demens. Fakta og utfordringer. (4 utgave) Tønsberg. Forlaget Aldring og helse.

Farran C J, Keane-Hagerty E. 1994. Interventions for caregivers of persons with dementia: educational support groups and Alzheimer's association support groups. Appl Nurs Res 7: 112-17.

Fearon M, Donaldson C, Burns A, Tarrier N. 1998. Intimacy as a determinant of expressed emotion in carers of people with Alzheimer's disease. Psychol Med 28: 1085-90.

Finkel, S. 2000. Introduction to behavioural and psychological symptoms of dementia (BPSD). Int J Geriatr Psychiatry 15: 2-4.

Fitting M, Rabins P, Lucas MJ, Eastham J. 1986. Caregivers for dementia patients: a comparison of husbands and wives. Gerontologist 26: 248-52.

Flint AJ. 1995. Effects of respite care on patients with dementia and their caregivers. Int Psychogeriatr 7: 505-17.

Folstein MF, Folstein SE, McHugh PR.1975. Mini-mental state. A practical method for grading the cognitive state of patients for the clinician. J Psychiatr Res 12: 189-98. 
Freyne A, Kidd N, Coen R, Lawlor BA. 1999. Burden in carers of dementia patients: higher levels in carers of younger sufferers. Int J Geriatr Psychiatry 14: 784-88.

Gallagher D, Rose J, Rivera P, Lovett S, Thompson LW. 1989. Prevalence of depression in family carergivers. Gerontologist 29: 449-56.

Gallagher-Thompson D, Coon DW. 2007. Evidence-based psychological treatments for distress in family caregivers of older adults. Psychol Aging 22:37-51.

Gallicchio L, Siddiqi N, Langenberg P, Baumgarten M. 2002. Gender differences in burden and depression among informal caregivers of demented elders in the community. Int $J$ Geriatr Psychiatry 17: 154-63.

Gelinas I, Gauthier L, McIntyre M, Gauthier S. 1999. Development of a functional measure for persons with Alzheimer's disease: the disability assessment for dementia (DAD). Am J Occup Ther 53: 471-81.

George LK, Gwyther LP. 1986. Caregiver well-being: a multidimensional examination of family caregivers of demented adults. Gerontologist 26: 253-59.

Gilhooly ML, Whittick JE. 1989. Expressed emotion in caregivers of the dementing elderly. Br J Med Psychol 62: 265-72.

Gold DP, Cohen C, Shulman K, Zucchero C, Andres D, Etezadi J. 1995. Caregiving and dementia: predicting negative and positive outcomes for caregivers. Int J Aging Hum Dev 41: 183-201.

Goldberg, DP. 1972. The detection of psychiatric illness by questionnaire. London: Oxford University Press.

Goldberg D. 1986. Use of the general health questionnaire in clinical work. Br Med J 293: 1188-89. 
Goldberg D, Williams P. 1988. A user's guide to the General Health Questionnaire. Berkshire: NFER-NELSON.

Graham C, Ballard C, Sham P. 1997. Carers' knowledge of dementia, their coping strategies and morbidity. Int J Geriatr Psychiatry 12: 931-36.

Green A, Brodaty H, Care-giver interventions. In: Qizilbash N, Scneider LS, Brodaty H, Tariot P, Kaye J, Chui H, Erkinjuntti T (eds). Evidence-based dementia practice. Hong Kong: Blackwell Publishing.

Greene JG, Smith R, Gardiner M, Timbury GC. 1982. Measuring behavioural disturbance of elderly demented patients in the community and its effects on relatives: a factor analytic study. Age Ageing 11: 121-26.

Gretarsdottir E, Woodruff-Borden J, Meeks S, Depp CA. 2004. Social anxiety in older adults: phenomenology, prevalence, and measurement. Behav Res Ther 42: 459-75

Haley WE, Levine EG, Brown SL, Berry JW, Hughes GH. 1987. Psychological, social, and health consequences of caring for a relative with senile dementia. J Am Geriatr Soc 35: 405-11.

Hebert R, Dubois MF, Wolfson C, Chambers L, Cohen C. 2001 Factors associated with long-term institutionalization of older people with dementia: data from the Canadian Study of Health and Aging. J Gerontol A Biol Sci Med Sci 56: 693-99.

Horowitz M, Wilner N, Alvarez W. 1979. Impact of Event Scale: a measure of subjective stress. Psychosom Med 41: 209-18.

Hosmer DW, Lemeshow S. 1989. Applied logistic regression. New York: Wiley.

International Statistical Classification of Diseases and Health Related Problems. ICD-10.

2004. Second Edition. $10^{\text {th }}$ Revision. Geneva. WHO. 
James IA, Powell I, Reichelt K. 2001. Cognitive therapy for carers: distinguishing fact from fiction. J Dementia Care 9: 24-26

Kaufer DI, Cummings JL, Christine D, Bray T, Castellon S, Masterman D, MacMillan A, et al. 1998. Assessing the impact of neuropsychiatric symptoms in Alzheimer's disease: the Neuropsychiatric Inventory Caregiver Distress Scale. J Am Geriatr Soc 46: 21015.

Kramer BJ. 1997. Differential predictors of strain and gain among husbands caring for wives with dementia. Gerontologist 37: 239-49.

Kvaal K, Ulstein I, Nordhus IH, Engedal K. 2005.The Spielberger State-Trait Anxiety Inventory (STAI): the state scale in detecting mental disorders in geriatric patients. Int J Geriatr Psychiatry 20: 629-34.

Lazarus RS, Folkman S. 1984. Stress, Appraisal, and Coping. New York: Springer.

Leff JP, Vaughn CE. Expressed emotion in families. New York. Guilford Press, 1985.

Lund Aa. 1991. A måtte ha et øye på hver finger. Sosialdepartementets utviklingsprogram om aldersdemens. Rapport nr. 1. Sem. Info-banken

Luscombe G, Brodaty H, Freeth S. 1998. Younger people with dementia: diagnostic issues, effects on carers and use of services. Int J Geriatr Psychiatry 13: 323-30.

Lutzky SM, Knight BG. 1994. Explaining gender differences in caregiver distress: the roles of emotional attentiveness and coping styles. Psychol Aging 9: 513-19.

Lyketsos CG, Steinberg M, Tschanz JT, Norton MC, Steffens DC, Breitner JC. 1999. Physical aggression in dementia patients and its relationship to depression. $\mathrm{Am} \mathrm{J}$ Psychiatry 156: 66-71. 
Lyketsos CG, Lopez O, Jones B, Fitzpatrick AL, Breitner J, DeKosky S. 2002. Prevalence of neuropsychiatric symptoms in dementia and mild cognitive impairment: results from the cardiovascular health study. JAMA 288: 1475-83.

Malt UF, Olafsen OM. 1992 Psychological appraisal and emotional response to physical injury: a clinical, phenomenological study of 109 adults. Psychiatr Med 10:117-34.

Mahoney R, Regan C, Katona C, Livingston G. 2005. Anxiety and depression in family caregivers of people with Alzheimer disease: the LASER-AD study. Am J Geriatr Psychiatry 13: 795-801.

MaloneBeach EE, Zarit SH, Spore DL. 1992 Caregivers' perceptions of case management and community-based services: barriers to service use. J Appl Gerontol 11: 146-59.

Marriott A, Donaldson C, Tarrier N, Burns A. 2000. Effectiveness of cognitive-behavioural family intervention in reducing the burden of care in carers of patients with Alzheimer's disease. Br J Psychiatry 176: 557-62.

Marvardi M, Mattioli P, Spazzafumo L, Mastriforti R, Rinaldi P, Polidori MC, Cherubini A. 2005. The Caregiver Burden Inventory in evaluating the burden of caregivers of elderly demented patients: results from a multicenter study. Aging Clin Exp Res 17: 46-53.

McKeith I, Cummings J. 2005. Behavioural changes and psychological symptoms in dementia disorders. Lancet Neurol 4: 735-42.

Miller B, Cafasso L. 1992. Gender differences in caregiving: fact or artifact? Gerontologist 32: 498-507.

Mittelman MS, Ferris SH, Steinberg G, Shulman E, Mackell JA, Ambinder A, Cohen J. 1993. An intervention that delays institutionalization of Alzheimer's disease patients: treatment of spouse-caregivers. Gerontologist 33: 730-40. 
Mittelman MS, Ferris SH, Shulman E, Steinberg G, Levin B. 1996. A family intervention to delay nursing home placement of patients with Alzheimer disease. A randomized controlled trial. JAMA 276: 1725-31.

Mittelman MS, Roth DL, Coon DW, Haley WE. 2004. Sustained benefit of supportive intervention for depressive symptoms in caregivers of patients with Alzheimer's disease. Am J Psychiatry 161: 850-56.

Mittelman MS, Haley WE, Clay OJ, Roth DL. 2006. Improving caregiver well-being delays nursing home placement of patients with Alzheimer disease. Neurology 67: 1592-99.

Montgomery SA, Asberg M. 1979. A new depression scale designed to be sensitive to change. Br J Psychiatry 134: 382-89.

Morris L W, Morris RG, Britton PG. 1988. The relationship between marital intimacy, perceived strain and depression in spouse caregivers of dementia sufferers. $\mathrm{Br} J \mathrm{Med}$ Psychol 61: 231-36.

Morris RG, Woods RT, Davis KS, Morris LW. 1991. Gender differences in carers of dementia sufferers. Br J Psychiatry Suppl 10: 69-74.

Motenko AK. 1989. The frustrations, gratifications, and well-being of dementia caregivers. Gerontologist 29:166-72.

Murphy SL, Williams CS, Gill TM. 2002. Characteristics associated with fear of falling and activity restriction in community-living older persons. $J$ Am Geriatr Soc 50: 516-20

Nelis SM, Quinn C, Clare L. 2007. Information and support interventions for informal caregivers of people with dementia. (Protocol) Cochrane Database Syst Rev, Issue 2: CD006440.

Novak M, Guest C. 1989. Application of a multidimensional caregiver burden inventory. Gerontologist 29: 798-803. 
Nygaard HA. 1988. Strain on caregivers of demented elderly people living at home. Scand J Prim Health Care 6: 33-37.

Ott A, Breteler MM, van Harskamp F, Stijnen T, Hofman A. 1998. Incidence and risk of dementia. The Rotterdam Study. Am J Epidemiol 147: 574-80.

Parks SH, Pilisuk M. 1991 Caregiver burden: gender and the psychological costs of caregiving. Am J Orthopsychiatry 61: 501-09.

Pearlin LI, Mullan JT, Semple SJ, Skaff MM. 1990. Caregiving and the stress process: an overview of concepts and their measures. Gerontologist 30: 583-94.

Pinquart M, Sorensen S. 2003. Associations of stressors and uplifts of caregiving with caregiver burden and depressive mood: a meta-analysis. J Gerontol B Psychol Sci Soc Sci 58:112-28

Pinquart M, Sorensen S. 2006. Helping caregivers of persons with dementia: which interventions work and how large are their effects? Int Psychogeriatr 18: 577-95.

Poulshock SW, Deimling GT. 1984. Families caring for elders in residence: issues in the measurement of burden. J Gerontol 39: 230-39.

Proctor R, Martin C, Hewison J. 2002. When a little knowledge is a dangerous thing...: a study of carers' knowledge about dementia, preferred coping style and psychological distress. Int J Geriatr Psychiatry 17: 1133-39.

Pruchno RA, Resch NL. 1989. Aberrant behaviors and Alzheimer's disease: mental health effects on spouse caregivers. J Gerontol 44: 177-182.

Qizilbash N. 2002. Evidence-based diagnosis. In: Qizilbash N, Scneider LS, Brodaty H, Tariot P, Kaye J, Chui H, Erkinjuntti T (eds). Evidence-based dementia practice. Hong Kong: Blackwell Publishing. 
Reisberg B, Ferris SH, de Leon MJ, Crook T. 1982 The Global Deterioration Scale for assessment of primary degenerative dementia. Am J Psychiatry 139: 1136-39.

Rinaldi P, Spazzafumo L, Mastriforti R, Mattioli P, Marvardi M, Polidori MC, Cherubini A. 2005. Predictors of high level of burden and distress in caregivers of demented patients: results of an Italian multicenter study. Int J Geriatr Psychiatry 20: 168-74.

Russo J, Vitaliano PP, Brewer DD, Katon W, Becker J. 1995. Psychiatric disorders in spouse caregivers of care recipients with Alzheimer's disease and matched controls: a diathesis-stress model of psychopathology. J Abnorm Psychol 104: 197-204.

Selbaek G, Kirkevold O, Engedal K. 2006. The prevalence of psychiatric symptoms and behavioural disturbances and the use of psychotropic drugs in Norwegian nursing homes. Int J Geriatr Psychiatry: Epub ahead of print

Selye H. 1936. A Syndrome Produced by Diverse Nocuous Agents. Nature 138: 32 (1998: reprint in Neuropsychiatry Clin Neurosci 10: 230-231.)

Selye H. 1976. Forty years of stress research: principal remaining problems and misconceptions. Can Med Assoc J 115: 53-6.

Schneider LS, Tariot PN, Lyketsos CG, Dagerman KS, Davis KL, Davis S, Hsiao JK. 2001. National Institute of Mental Health Clinical Antipsychotic Trials of Intervention Effectiveness (CATIE): Alzheimer disease trial methodology. Am J Geriatr Psychiatry 9: 346-60.

Schulz R, Vistainer P, Williamson GM. 1990. Psychiatric and physical morbidity effects of caregiving. J Gerontol 45: 181-91.

Schulz R, Williamson GM. 1991. A 2-year longitudinal study of depression among Alzheimer's caregivers. Psychol Aging 6: 569-78. 
Schulz R, O'Brien AT, Bookwala J, Fleissner K.1995. Psychiatric and physical morbidity effects of dementia caregiving: prevalence, correlates, and causes. Gerontologist 35: 771-91.

Schulz R, O'Brien A, Czaja S, Ory M, Norris R, Martire LM, Belle SH. 2002. Dementia caregiver intervention research: in search of clinical significance. Gerontologist 42: 589-602.

Sorensen S, Pinquart M, Duberstein P. 2002 How effective are interventions with caregivers? An updated meta-analysis. Gerontologist 42: 356-72.

Spielberger CD, Gorsuch RL, Lushene RE, Vagg PR, Jacobs AG. 1970. Manual for the State-Trait Anxiety Inventory. Consulting Psychologists Press, Inc., Palo Alto.

Spielberger CD, Gorsuch RL, Lushene PR, Vagg PR, Jacobs AG. 1983. Manual for the Staite-Traite Anxiety Inventory (FormY). Consulting Psychologists press, Inc., Palo Alto.

Steffen AM, McKibbin C, Zeiss AM, Gallagher-Thompson D, Bandura A. 2002. The revised scale for caregiving self-efficacy: reliability and validity studies. $J$ Gerontol $B$ Psychol Sci Soc Sci 57: 74-86.

Strain LA, Blandford AA, Mitchell LA, Hawranik PG. 2003. Cognitively impaired older adults: risk profiles for institutionalization. Int Psychogeriatr 15: 351-66.

Summers WK, Majovski LV, Marsh GM, Tachiki K, Kling A.1986. Oral tetrahydroaminoacridine in long-term treatment of senile dementia, Alzheimer type. N Engl J Med 315: 1241-45.

Sundin EC, Horowitz MJ. 2002. Impact of Event Scale: psychometric properties. $\mathrm{Br} J$ Psychiatry 180: 205-09.

Teri L.1997.Behavior and caregiver burden: behavioral problems in patients with Alzheimer disease and its association with caregiver distress. Alzheimer Dis Ass Dis 11: 35-S38. 
Thompson C, Spilsbury K. 1998. Support for carers of people with Alzheimer's type dementia. Cochrane Database Syst Rev Issue 3: CD000454. Withdrawn.

Thompson RL, Lewis Sl, Murphy MR, Hale JM, Blackwell PH, Acton GJ, Clough DH, et al. 2004. Are there sex differences in emotional and biological responses in spousal caregivers of patients with Alzheimer's disease? Biol Res Nurs 5: 319-30.

Ulstein I, Lillehovde E. 2000. Fylkeskommunal hukommelsesklinikk. Erfaringer etter halvannet års drift. Demens 4: 14-17.

Vaughn CE, Leff JP. 1976. The measurement of expressed emotion in the family of psychiatric patients. Br J Clin Soc Psychol 15: 157-265.

Vedhara K, Shanks N, Anderson S, Lightman S. 2000. The role of stressors and psychosocial variables in the stress process: a study of chronic caregiver stress. Psychosom Med 62: $374-85$.

Vernooij-Dassen M, Downs M. 2005. Cognitive and behavioural interventions for carers of people with dementia. (Protocol) Cochrane Database Syst Rev Issue 2: CD005318

Vitaliano PP, Russo J, Young HM, Becker J, Maiuro RD. 1991. The screen for caregiver burden. Gerontologist 31: 76-83.

Vitaliano PP, Russo J, Young HM, Teri L, Maiuro RD. 1991. Predictors of burden in spouse caregivers of individuals with Alzheimer's disease. Psychol Aging 6: 392-402.

Vitaliano PP, Young HM, Russo J, Romano J, Magana-Amato A. 1993. Does expressed emotion in spouses predict subsequent problems among care recipients with Alzheimer's disease? J Gerontol 48: 202-09.

Weiss D, Marmar C. 1997. The Impact of Events-Scale-Revised. In: J Wilson \& Keane (eds). Assessing psychological trauma and PTSD. New York: Guillford Press. 
Whittick, J. 1993. Expressed emotion and coping techniques among carers of the dementing elderly. In: Jones G, Miesen BML (eds). Caregiving in dementia. Routledge.

Winslow BW, Carter P. 1999. Patterns of burden in wives who care for husbands with dementia. Nurs Clin North Am 34: 275-87.

Øksnvad AL, Grønnestad T, Arntzen, Bente. 2000. In: Familiearbeid ved psykoser. Mot samme mål. Stavanger: Stiftelsen Psykiatrisk Opplysning.

Zarit SH, Reever KE, Bach-Peterson J. 1980. Relatives of the impaired elderly: correlates of feelings of burden. Gerontologist 20: 649-55.

Zarit SH, Todd PA, Zarit JM. 1986. Subjective burden of husbands and wives as caregivers: a longitudinal study. Gerontologist 26: 260-66.

Zarit SH, Edwards AB. 1996. Family Caregiving: research and clinical intervention. In Woods RT (ed). Handbook of Clinical Psychology of Aging. Chichester: John Wiley\& Sons.

Zarit SH, Stephens MA, Townsend A, Greene R. 1998. Stress reduction for family caregivers: effects of adult day care use. J Gerontol B Psychol Sci Soc Sci 53: 267277.

Zigmond AS, Snaith RP. 1983. The hospital anxiety and depression scale. Acta Psychiatr Scand 67: 361-70.

Zung WW. 1965. A self-rating depression scale. Arch Gen Psychiatry 12: 63-70.

Yesavage JA, Brink TL, Rose TL, Lum O, Huang V, Adey M, Leirer VO. 1982. Development and validation of a geriatric depression screening scale: a preliminary report. J Psychiatr Res 17: 37-49. 


\section{Errata}

Paper III: The following sentences were erroneous in the original manuscript and are corrected. The corrections are underlined:

Page 2 - Abstract/Results, last sentence: This moderate to high stress response was independently explained by being a spouse (OR 3.74 (95\% CI $1.81-7.74)$ ), high scores on GDS (OR 1.12 (95\% CI 1.06 - 1.18) per unit increase) and high score on NPI-D (OR 1.05 (95\% CI 1.01-1.09) per unit increase).

Page 8 - Results, last sentence: Variables explaining 'stress response' were the carer being a spouse, regardless of being a wife or husband, GDS, and NPI-D. 